
\title{
RELATOS DE PESQUISAS
COMPETÊNCIAS EMPREENDEDORAS PARA PRESTAÇÃO
DE SERVIÇOS DE INFORMAÇÃO POR BIBLIOTECÁRIOS
NO BRASIL ${ }^{1}$
}

\author{
Crichyna da Silva Madalena \\ Mestre em Gestão da Informação pela Universidade Federal de Santa \\ Catarina, Brasil. \\ E-mail: crichyna.sm@gmail.com
}

Daniela Spudeit

Doutoranda em Ciência da Informação pela Universidade Federal de Santa Catarina, Brasil. Professora da Universidade do Estado de Santa Catarina, Brasil.

E-mail: danielaspudeit@gmail.com

Marli Dias de Souza Pinto

Doutora em Engenharia da Produção pela Universidade Federal de Santa

Catarina, Brasil. Professora da Universidade Federal de Santa Catarina,

Brasil.

E-mail: marli.dias@ufsc.br

\begin{abstract}
Resumo
Analisa as competências empreendedoras dos bibliotecários que possuem empresas na área de Gestão da Informação no Brasil. Para isso, busca conhecer as competências empreendedoras segundo a literatura, identificar os bibliotecários que possuem empresa no Brasil e os serviços prestados na área de gestão da informação, verifica a formação destes bibliotecários e a percepção dos mesmos quanto às competências requeridas para empreender na área. Caracteriza-se como pesquisa descritiva, exploratória, bibliográfica com abordagem qualitativa. Foi usada a técnica de conteúdo de Bardin na análise dos dados. $\mathrm{O}$ universo foi composto por bibliotecários brasileiros mapeados via contato com entidades de classe e pelo Portal EmpreendeBiblio, totalizando 46 bibliotecários que aceitaram participar da pesquisa e responderam um questionário. Para analisar as competências, foi utilizado o modelo conceitual de Cooley (1990) baseado em um conjunto com dez competências empreendedoras. Os resultados apontam para a predominância do gênero feminino entre os profissionais empreendedores e que estão na faixa etária entre 31 e 40 anos; as empresas se localizam principalmente em São Paulo, Rio de Janeiro e Santa Catarina, sendo que grande parte delas está formalizada e possui negócios voltados para a gestão de documentos e arquivos convencionais e digitais, consultoria na elaboração de projetos, organização de bibliotecas, normalização de trabalhos e projetos, entre outros serviços. Em relação às competências empreendedoras, os bibliotecários participantes da pesquisa apontaram que as mais importantes são: comprometimento, busca de informações, persuasão, rede de contatos e persistência. Embora os bibliotecários tenham indicado que possuem todas as competências empreendedoras apontadas no modelo conceitual de Cooley, há uma tendência de que algumas são mais importantes do que outras conforme o nicho de atuação escolhido dentro da área de gestão da informação. Por fim, com base em todas as informações obtidas, elaborouse um mapa de competências para nortear possíveis bibliotecários que queiram empreender na área de gestão da informação.
\end{abstract}

\footnotetext{
${ }^{1}$ Trabalho resultante da pesquisa de mestrado realizada no Programa de Pós-Graduação em Gestão da Informação da Universidade do Estado de Santa Catarina (UDESC) entre 2016 e 2018. A dissertação completa está disponível em http://www.faed.udesc.br/arquivos/id submenu/3015/crichyna da silva madalena.pdf.
} 
Palavras-chave: Empreendedorismo. Biblioteconomia. Competência empreendedora. Serviço de informação.

\title{
ENTREPRENEURSHIP COMPETENCIES FOR THE PROVISION OF INFORMATION SERVICES BY LIBRARIANS IN BRAZIL
}

\begin{abstract}
This work aims to analyze the entrepreneurial skills of librarians who have companies in the area of Information Management in Brazil. In order to do this, we sought to know the entrepreneurial skills according to the literature, the librarians who have a company in Brazil and the services provided, the entrepreneurial training of these librarians and their perception of the skills required to undertake new businesses. The universe was composed of Brazilian librarians mapped through contact to class entities and via Portal EmpreendeBiblio, totalizing 46 librarians who accepted to participate in the research. To analyze the competences, the conceptual model of entrepreneurial skills of Cooley (1990) was used. The results point to the predominance of the female gender among the entrepreneurial librarians, in the age range between 31 and 40 years; the companies are located mainly in São Paulo, Rio de Janeiro and Santa Catarina, most of which are formalized and have business oriented to the management of conventional and digital documents and files, consulting in the elaboration of projects, organization of libraries, standardization of works and projects, among other services. Most of them took specialization courses. Regarding the category of entrepreneurship competences, it is evidenced by the participating librarians that the most important ones were commitment, information search, persuasion, networking and persistence. Finally, based on all the information obtained, a map of enterprising skills of the librarians was elaborated. It was concluded that, although librarians have indicated that they possess all entrepreneurial skills, there is a tendency that some skills are more important than others.
\end{abstract}

Keywords: Entrepreneurship. Librarianship. Entrepreneurial competence. Information service.

\section{ASPECTOS INTRODUTÓRIOS}

A atuação dos profissionais de Biblioteconomia está cada vez menos limitada somente aos espaços tradicionais compostos por bibliotecas escolares, universitárias, públicas ou mesmo especializadas, pois novas frentes de trabalho apareceram desde a década de 1990 com as mudanças oriundas devido principalmente à inserção de tecnologias da informação e comunicação no fazer profissional. Vemos atualmente bibliotecários atuando com atividades ligadas à inteligência competitiva, gestão de projetos, comércio eletrônico, gestão de dados, arquitetura da informação, gestão de sistemas de informação, mapeamento de fontes especializadas para pesquisadores, advogados, médicos, entre outras que extrapolam os espaços físicos e tradicionais das bibliotecas.

As mudanças advindas da pós-sociedade industrial, também chamada Sociedade da Informação, com a inserção de tecnologias diferenciadas e o fenômeno relacionado à globalização, contribuíram para as mudanças no fazer profissional dos bibliotecários, bem como na transformação e ampliação dos espaços de atuação, exigindo que esses profissionais aprendam e desenvolvam novas competências.

Desse modo, a relação entre a Sociedade da Informação e o bibliotecário faz-se de tal modo que leva os profissionais a adotarem uma nova postura de trabalho, no qual precisam conhecer quais são os recursos e as tecnologias de informação e comunicação que podem ser implementadas para empreender e desenvolver serviços diferenciados para atender demandas específicas.

Perspectivas em Gestão \& Conhecimento, João Pessoa, v. 9, n. 3, p. 102-129, set./dez. 2019. 
Sendo assim, no que se refere à atuação do bibliotecário em bibliotecas tradicionais, Pereira (2014) afirma que esse local é importante, mas não é apenas o único espaço de atuação do bibliotecário, por mais que as instituições de ensino superior voltem sua formação para esse segmento. É fundamental que o bibliotecário entenda que ele é um profissional apto para atuar em qualquer outro tipo de ambiente que tenha como objeto central a informação. Além disso, existem os profissionais que não têm vocação e/ou interesse em atuar nesses espaços tradicionais e podem buscar novas oportunidades em outros ambientes que necessitem da gestão da informação.

Identificar oportunidades no mercado de trabalho para o bibliotecário é necessário, em decorrência das novas formas de trabalho em relação à prestação de serviços como profissionais liberais. Discutir sobre os espaços de atuação do bibliotecário, assim como de qualquer outra profissão, não consiste apenas em atividades relacionadas ao seu ofício, mas, sobretudo, compreender que todas as profissões estão relacionadas ao saber (conhecimento), ao saber-fazer (habilidade) e também a um querer saber-fazer (atitude/comportamento) que compõe o que é competência.

Além disso, Minarelli (1995), Silva e Sales (2012) alertam que os tipos de vínculos empregatícios estão mudando e concedendo espaços para novas abordagens profissionais, abrindo o leque de atuação do bibliotecário como técnico, consultor, prestador de serviços e como empreendedor, em um cenário no qual o mercado de trabalho está em expansão, exigindo que o profissional desenvolva novas competências para lidar com os fluxos informacionais e, por consequência, ampliar os espaços de atuação. Nesse sentido, o bibliotecário pode ser um empresário da informação, que conforme Le Coadic (2004, p. 38) indica "[...] é constituído por profissionais da informação que criam empresas de fabricação e venda de produtos ou serviços de informação".

O trabalho autônomo é uma das novas possibilidades de atuação para o bibliotecário, já que ele é um profissional qualificado para oferecer seus serviços de acordo com competências específicas na área de informação (BAPTISTA, 1998; PINHEIRO; FRANCO; GRAÇA, 1987; RODRIGUES, 2014; SANTA ANNA; PEREIRA, 2014).

Para atender a essas demandas, o bibliotecário precisa se qualificar para acompanhar as mudanças de mercado de trabalho e os recursos disponíveis, buscando por uma educação continuada de modo a desenvolver e aperfeiçoar suas competências empreendedoras. A educação continuada é uma ferramenta cuja finalidade é melhorar o desempenho profissional, a fim de possibilitar o desenvolvimento de competências para o aperfeiçoamento de conhecimentos, habilidades e atitudes.

Segundo Marchiori (2002), na literatura são retratadas as competências individuais, profissionais e das organizações como responsáveis pelas atividades de informação e aprendizado voltadas para a sociedade, de forma a impulsionar a economia voltada para a produção de bens, serviços e atividades de informação. Assim sendo, o domínio de determinadas competências é fundamental para que o bibliotecário se diferencie no mercado, de modo a estar preparado para atender as demandas do trabalho na contemporaneidade.

Esta pesquisa contribui, mostrando as competências empreendedoras, por meio de casos reais de bibliotecários que estão desbravando novos campos de atuação no Brasil e, a partir disso, empreendendo na prestação de serviços na área de gestão da informação. Para tanto, partiu-se da seguinte questão norteadora: Quais competências o bibliotecário precisa desenvolver para empreender na área de gestão da informação no contexto nacional?

Para responder à questão de pesquisa, estabeleceu-se como objetivo principal analisar as competências empreendedoras dos bibliotecários que possuem empresas na área de Gestão da Informação. Para isso, buscou-se conhecer as competências empreendedoras segundo a literatura, identificou-se os bibliotecários que têm empresas no Brasil e os tipos de serviços prestados, verificou-se a formação empreendedora desses bibliotecários, apresentou-

Perspectivas em Gestão \& Conhecimento, João Pessoa, v. 9, n. 3, p. 102-129, set./dez. 2019. 
se a percepção dos bibliotecários empreendedores quanto às competências requeridas para empreender e, por fim, criou-se um mapa de competências empreendedoras para bibliotecários que queiram empreender.

\title{
2 EMPREENDEDORISMO
}

Hashimoto (2006), Dolabela (2008) e Dornelas (2008) retratam que muito se fala sobre o empreendedorismo a nível mundial desde o início dos anos 2000. Baron e Shane (2010) apontam três fatores que influenciaram o interesse pelo tema: o primeiro, foram os casos de sucesso de empreendedores que começaram a surgir na mídia, como Bill Gates; no ambiente de instabilidade no emprego decorrente de demissões e reestruturações oriundas da globalização e abertura de mercados internacionais; e, por último, a escolha das pessoas por um estilo de vida mais independente. Na mesma linha, Lapolli, Rosa e Franzzoni (2009) explicam que o empreendedorismo vem evoluindo por conta das mudanças econômicas e sociais ocorridas nos últimos anos, criando assim a necessidade de competitividade e competência na oferta de produtos e serviços no mercado.

O empreendedorismo pode ser entendido como um processo dinâmico de geração de riquezas, mediante a transformação de conhecimentos em produtos e serviços, com competências e recursos necessários e está ligado à habilidade de identificar novas oportunidades. Dessa forma, o empreendedorismo:

\begin{abstract}
Refere-se ao desenvolvimento de habilidades e espírito empreendedor pelos aprendizes, de modo que se tornem capazes de transformar ideias criativas em ação, sendo uma competência-chave, transversal e aplicável pelas pessoas, grupos e organizações a quaisquer situações e contextos suportando o desenvolvimento pessoal, cidadania ativa, inclusão social e empregabilidade. (LOPES; LIMA; NASSIF, 2017, p. 23).
\end{abstract}

O empreendedorismo é visto e associado à pessoa ou à ação de criar um negócio ou uma empresa. Contudo, conforme está presente no discurso de alguns autores, o empreendedorismo é mais abrangente, é por vezes tomada de postura, de comportamento em outros processos de criação e desenvolvimento.

\begin{abstract}
Pode ser compreendido como a arte de fazer acontecer com criatividade e motivação. Consiste no prazer de realizar, com sinergismo e inovação, qualquer projeto pessoal ou organizacional, em desafio permanente às oportunidades e aos riscos. É assumir um comportamento proativo diante de questões que precisam ser resolvidas. O empreendedorismo é o despertar do indivíduo para o aproveitamento integral de suas potencialidades racionais e intuitivas. É a busca do autoconhecimento em processo de aprendizado permanente, em atitude de abertura para novas experiências e novos paradigmas (BAGGIO; BAGGIO, 2014, p. 26).
\end{abstract}

Almeida e Zouain (2016) retratam em sua pesquisa os principais artigos e autores internacionais, cujo objeto de estudo é o empreendedorismo: Schumpeter (1934), Kirzner (1973), Eisenhardt (1989), Barbey (1991) e Shane (2000). Observa-se que o tema empreendedorismo vem sendo campo de pesquisa mundialmente desde a década de $1940 \mathrm{e}$ que tem crescido de forma constante nos últimos anos.

De acordo com Dornelas (2008, p. 7): "[...] o crescimento do empreendedorismo no mundo se acelerou na década de 1990 e aumentou em proporção nos anos 2000". Esse período, segundo Yano e Monteiro (2008, p. 2), foi marcado por transformações de "[...] 
caráter estrutural ocorridas nos ambientes econômico e institucional, ligadas tanto ao novo conjunto de políticas econômicas adotado, quanto à implementação de reformas de cunho liberalizante". Ou seja, o dinamismo empresarial e os fatores econômicos apontaram para o empreendedorismo como uma possibilidade para o crescimento econômico, político e social do país. Porém, para atender essas transformações e demandas, torna-se necessário que os profissionais desenvolvam competências empreendedoras.

Três autores desenvolveram suas teorias sobre a definição do empreendedor, que impulsionaram linhas de pensamento que impactam até os dias atuais. Dessa forma, Richard Cantillon, Jean-Baptist Say e Joseph Alois Schumpeter foram os pioneiros a fazer uma reflexão sobre empreendedorismo. O perfil era daquele sujeito que assumia riscos, que criava valor e que era agente de um processo de destruição criativa (CANTILLON, 1755; SAY, 1803; SCHUMPETER, 1934 apud HISRICH, PETERS, 2004). Atualmente, em pleno século XXI, o empreendedor é aquela pessoa criativa, marcada pela capacidade de estabelecer e atingir objetivos, tem a necessidade de realizar coisas novas, pôr em prática suas próprias ideias, consegue fazer as coisas acontecerem, ou seja, ser empreendedor é mais do que criar novos negócios, novos produtos, novas oportunidades, é um estilo de vida, uma decisão de vida (FILION, 1999; DEGEN, 2005; SOUZA, 2013).

Nessa perspectiva, Degen (2009) acentua a importância de se definir um perfil do empreendedor bem-sucedido. Para ele esse empreendedor é:

\begin{abstract}
Alguém que não se conforma com os produtos e serviços disponíveis no mercado e procura melhorá-los; alguém que, por meio de produtos e serviços, procura superar os existentes no mercado; alguém que não se intimida com as empresas estabelecidas e as desafia com seu novo jeito de fazer as coisas (DEGEN, 2009, p. 15).
\end{abstract}

Dentro dessa perspectiva de perfil profissional, torna-se necessário desenvolver competências empreendedoras para atender às demandas do mercado e se tornar competitivo. Rabaglio (2001) e Fleury e Fleury (2001) definem competências como sendo um conjunto de conhecimentos, habilidades, atitudes e comportamentos que permitam ao indivíduo desempenhar com eficácia determinadas tarefas, em qualquer situação, por isso se relaciona a um saber agir responsável e reconhecido, que implica mobilizar, integrar, transferir conhecimentos, recursos e habilidades, que agreguem valor econômico à organização e valor social ao indivíduo.

Cooley (1990), Man, Lau e Chan (2002), McClelland (1961) são alguns dos autores internacionais que estudam a questão das competências empreendedoras como fator de sucesso nas atividades laborais. As competências empreendedoras, para Antonello (2005), se refere ao conjunto de conhecimentos, habilidades e atitudes que possibilitam a um indivíduo visualizar suas estratégias e ações na criação de valor (tangíveis ou intangíveis) para a sociedade. A autora defende que as competências necessárias para o empreendedor se adaptam conforme o contexto de cada negócio, devendo o profissional desenvolver sua capacidade de leitura de contextos e verificação de demandas. Nesse mesmo raciocínio, Lenzi (2008, p. 46) afirma que "[...] assim como uma pessoa pode lapidar suas próprias competências, um empreendedor pode construir e adequar suas individualidades a fim de criar uma competência empreendedora". Dessa forma, este trabalho procurou analisar as competências empreendedoras dos bibliotecários que possuem empresas na área de Gestão da Informação no Brasil. 


\section{EMPREENDEDORISMO NA BIBLIOTECONOMIA}

Empreender na Biblioteconomia é um desafio por envolver mudanças de hábitos, comportamentos, perfis e competências. É sobretudo ter uma visão empreendedora para se enxergar como um profissional liberal e que pode exercer seu trabalho fora dos das bibliotecas (SPUDEIT, 2016). Sabe-se que na área da Biblioteconomia o empreendedorismo e a prestação de serviços por bibliotecário ainda são pouco disseminados (ALVES; DAVOK, 2009).

Porém, estudos nessa área vêm aumentando e mencionando essa nova área de atuação do bibliotecário conforme levantamento feito nas principais bases de dados como BRAPCI, BENANCIB, BDTD/IBICT e SCIELO na área de Biblioteconomia e Ciência da Informação no Brasil. Nestas bases, há registro de que em 2005, foram publicadas as primeiras pesquisas na área do Empreendedorismo e Consultoria na Biblioteconomia, tais como: Fonseca, Fonseca e Fonseca (2005); Dalpian, Fragoso e Rozados (2007); Alves e Davok (2009); Milano e Davok (2009); Bernardes e Blattmann (2011); Valentim et al. (2011); Silveira (2012); Santa Anna e Pereira (2014); Bezerra (2015); Spudeit (2016); Fonseca e Mota (2016); Candido, Vianna e Bedin (2016). Estes estudos demonstram que empreendedorismo é pouco explorado na área, e por isso, há necessidade de expandir debates sobre a temática. Também apresentam o perfil e características necessárias para empreender, apontam um novo campo de atuação para os bibliotecários, ressaltam a importância do bibliotecário se adequar as mudanças mercadológicas ocasionadas pela globalização e destacam a competência do bibliotecário associada às peculiaridades do empreendedorismo como fator diferencial no mercado de trabalho em expansão.

Não obstante, se verifica na literatura da área que ainda são poucos bibliotecários que buscam no empreendedorismo uma nova atuação. Contudo, há um mercado potencialmente favorável para ser explorado pelos bibliotecários. Esta circunstância é associada à ideia de Valentim (1998, p.112) ao afirmar que "nestes últimos anos verifica-se um crescimento na atuação do profissional bibliotecário como consultor, assessor, autônomo ou mesmo terceirizado. No entanto, sabe-se que é uma minoria e que isso precisa ser mais instigado nas Escolas de Biblioteconomia, seja por meio de disciplinas obrigatórias e optativas, organização e participação em projetos em empresa júnior, projetos de extensão ou mesmo de pesquisa, organização de eventos específicos voltados para prestação de serviços de informação conforme foi apontado por Spudeit et al. (2019).

No que tange aos serviços de informação, é importante destacar que eles restabelecem uma nova oportunidade de negócio para o bibliotecário, principalmente, no que se refere a oferecer com qualidade e eficiência os serviços que o cliente deseja. Entre os serviços na área de gestão da informação que podem ser desenvolvidos pelos bibliotecários, pode-se citar: plataformas para editoração de periódicos e jornais, revistas, livros, normalização acadêmica, elaboração de currículo lattes e ficha catalográfica, realização de cursos e eventos, consultoria na elaboração de projetos, tratamento de documentos, gestão de arquivos físicos e digitais, comercialização de produtos sobre Biblioteconomia, mapeamento e documentação de processos, hospedagem em nuvens, entre outros. Para o bibliotecário que deseja empreender, pode-se explorar a área de gestão de serviços de informação, atuando em diversos segmentos tais como:

Analista de Inteligência Competitiva (atendendo o e-commerce, por exemplo) Consultor de Informação (para serviços especializados), Analista de Buscas (em portais de informação, plataformas de inteligência, ou plataformas de informação integrada), Arquitetos de Informações, Gestor de Conteúdo na Web, entre outros. (ROMEIRO; SPUDEIT, 2016, p. 103).

Perspectivas em Gestão \& Conhecimento, João Pessoa, v. 9, n. 3, p. 102-129, set./dez. 2019. 
Pode-se perceber que existe uma gama de serviços de informação que podem ser ofertados, assim como outros campos a serem explorados com a finalidade de atender diferentes demandas, sendo elas de instituições públicas, privadas ou sem fins lucrativos, entretanto é necessário verificar qual mercado, qual nicho vai atender, quais as necessidades, qual a estrutura desejada, quais as tecnologias, quais os custos envolvidos, quais os riscos esperados, assim como quais as competências requeridas. Será sobre esse último ponto que se relaciona às competências é que essa pesquisa foi desenvolvida e cujos procedimentos metodológicos são apresentados na próxima seção.

\section{PROCEDIMENTOS METODOLÓGICOS}

Trata-se de uma pesquisa aplicada com abordagem qualitativa ao investigar as necessidades e percepção dos bibliotecários em relação à atuação profissional como empreendedor e demanda do mercado. Quanto aos objetivos, esta pesquisa classifica-se como exploratória e descritiva, porque buscou analisar e descrever quem são os bibliotecários que estão empreendendo no Brasil e suas competências empreendedoras para entender como desenvolvem as práticas empreendedoras.

O universo foi composto por bibliotecários brasileiros que criaram empresas formais ou que prestam serviços na área de gestão da informação com consultorias, mapeados por meio de contato com entidades de classe (associações profissionais, conselhos regionais e sindicatos da área), nas juntas comerciais estaduais e também via portal EmpreendeBiblio, para que fosse possível enviar um questionário de coleta de dados. Foram mapeadas 55 empresas criadas por bibliotecários. Desse total foram identificados 60 bibliotecários, sendo que 46 responderam integralmente à pesquisa e foram validados para a abordagem deste estudo.

As categorias de análise usadas na pesquisa foram: caracterização dos pesquisados, perfil da empresa, formação e competências empreendedoras. Para tanto, a técnica de Bardin (2011) foi aplicada da seguinte forma: a pré-análise permitiu a leitura para a construção das ideias. A exploração do material consistiu em codificar os dados, ou seja, transcrever do questionário as perguntas e respostas abertas e estabelecer categorias para as perguntas fechadas. Para o tratamento dos resultados, foram agrupadas as respostas semelhantes, de modo, a estabelecer conexões entre os fatos e possíveis explicações.

Além disso, a pesquisa utilizou a combinação de diferentes fontes e métodos de coleta e interpretação de dados. Esse fenômeno é denominado triangulação e tem a finalidade de combinar métodos e/ou fontes de coleta de dados qualitativos e quantitativos (entrevistas, questionários, documentos, entre outros), assim como diferentes métodos de análise dos dados, como a análise de conteúdo, a análise de discurso além de outras (AZEVEDO et al., 2013). Assim, a triangulação nessa pesquisa consistiu em confrontar os autores utilizados na bibliografia, documentos e análise dos questionários alinhados ao contexto social, político, econômico no Brasil.

Para o constructo do tema competências empreendedoras e em consonância com os objetivos propostos por esta pesquisa, convém ressaltar o trabalho de Lenzi (2008), o qual aborda o trabalho desenvolvido por Cooley (1990), que desenvolveu uma tipologia que permite de maneira simples a identificação das competências empreendedoras, ou seja, uma metodologia que possibilita a identificação das competências empreendedoras necessárias ao desenvolvimento das atividades profissionais. O modelo agrupa 10 competências empreendedoras em três conjuntos e com trinta perguntas, ou seja, três para cada competência conforme apresentado no Quadro 1: 
Quadro 1 - Competências Empreendedoras

CONJUNTO DE REALIZAÇÃO

BUSCA DE OPORTUNIDADES E INICIATIVA (BOI)

Lidera ou executa novos projetos, ideias e estratégias que visam conceber, reinventar, produzir ou comercializar novos produtos ou serviços.

Toma iniciativas pioneiras de inovação gerando novos métodos de trabalho, negócios, produtos ou mercados para empresa.

Produz resultado para empresa decorrente da comercialização de produtos e serviços gerados da oportunidade de negócio que identificou e captou no mercado.

CORRER RISCOS CALCULADOS (CRC)

Avalia o risco de suas ações na empresa ou no mercado por meio de informações coletadas.

Age para reduzir os riscos das ações propostas.

Está disposto a correr riscos, pois eles representam um desafio pessoal e poderão de fato trazer bom retorno para a empresa.

EXIGÊNCIA DE QUALIDADE E EFICIÊNCIA (EQE)

Suas ações são muito inovadoras, trazendo qualidade e eficácia nos processos.

É reconhecido por satisfazer seus clientes internos e externos por meio de suas ações e resultados

Estabelece prazos e os cumpre com padrão de qualidade reconhecido por todos.

PERSISTÊNCIA (PER)

Age para driblar ou transpor obstáculos quando eles se apresentam

Não desiste em situações desfavoráveis e encontra formas de atingir os objetivos.

Admite ser responsável por seus atos e resultados, assumindo a frente para alcançar o que é proposto. COMPROMETIMENTO (COM)

Conclui uma tarefa dentro das condições estabelecidas, honrando os patrocinadores e parceiros internos.

Quando necessário, "coloca a mão na massa" para ajudar a equipe a concluir um trabalho.

Está disposto a manter os clientes (internos e externos) satisfeitos e de fato consegue.

CONJUNTO DE PLANEJAMENTO

BUSCA DE INFORMAÇÕES (BDI)

Vai pessoalmente atrás de informações confiáveis para realizar um projeto.

Investiga pessoalmente novos processos para seus projetos ou ideias inovadoras.

Quando necessário, consulta pessoalmente especialistas para lhe ajudar em suas ações.

ESTABELECIMENTO DE METAS (EDM)

Define suas próprias metas, independente do que é imposto pela empresa.

Suas metas são claras e específicas, e entendidas por todos os envolvidos.

Suas metas são mensuráveis e perfeitamente acompanhadas por todos da equipe.

PLANEJAMENTO E MONITORAMENTO SISTEMÁTICOS (PMS)

Elabora planos com tarefas e prazos bem definidos e claros.

Revisa constantemente seus planejamentos, adequando-os quando necessário.

É ousado na tomada de decisões, mas se baseia em informações e registros para projetar resultados.

CONJUNTO DE PODER

PERSUASÃO E REDE DE CONTATOS (PRC)

Consegue influenciar outras pessoas para que sejam parceiros em seus projetos viabilizando recursos necessários para alcançar os resultados propostos.

Consegue utilizar pessoas-chave para atingir os resultados que se propõe ou conseguir os recursos

necessários.

Desenvolve e fortalece sua rede de relacionamento interna e externa à empresa.

INDEPENDÊNCIA E AUTOCONFIANÇA (IAC)

Está disposto a quebrar regras, suplantar barreiras e superar obstáculos já enraizados na empresa.

Confia em seu ponto de vista e o mantém mesmo diante de oposições.

É confiante nos seus atos e enfrenta desafios sem medo.

$$
\text { Fonte: Cooley (1990) }
$$

Perspectivas em Gestão \& Conhecimento, João Pessoa, v. 9, n. 3, p. 102-129, set./dez. 2019. 
As competências empreendedoras citadas por Cooley (1990) resultam em uma tipologia que possibilita de maneira simples, a identificação das competências empreendedoras e é amplamente utilizado por diversos pesquisadores, por isso, foi o modelo conceitual adotado para esta pesquisa conforme resultados são apresentados na próxima seção.

\section{APRESENTAÇÃO E ANÁLISE DOS RESULTADOS}

Inicialmente, caracterizaram-se os sujeitos pesquisados e percebe-se que houve uma predominância do gênero feminino (74\%) em relação ao masculino (26\%). Segundo dados do Global Entrepreneurship Monitor (GEM): “[...] as mulheres brasileiras conseguem criar novos negócios na mesma proporção que os homens, porém enfrentam mais dificuldades para fazer seus empreendimentos prosperarem". (GLOBAL ENTREPRENEURSHIP MONITOR, 2017, p. 35) Tal fato ocorre, segundo o referido relatório do GEM (2017), por sofrerem preconceito de gênero e pela baixa credibilidade por associarem que o mundo dos negócios é tradicionalmente explorado por homens, entre outros aspectos. Entretanto, a presente pesquisa mostra que as bibliotecárias estão se destacando no cenário empreendedor (74\%), pelo menos nessa categoria profissional.

Em relação à idade dos respondentes, constata-se que a faixa etária varia entre 31 e 40 anos e mais de 51 anos, ambas com $35 \%$ das respostas, seguindo-se os bibliotecários que têm entre 41 e 50 anos, com $19 \%$ e, de 21 a 30 anos, com 11\% das respondentes.

Infere-se que os bibliotecários que estão empreendendo possuem mais experiência profissional e de vida. Corroborando, Fillon (1999, p. 12) afirma que "[...] quanto mais velho for o empreendedor, maior será a influência dos contatos com o meio de negócios ou da experiência prévia e das atividades de aprendizagem".

No que tange à empresa, houve uma maior concentração de empreendedores na região Sudeste, com destaque para os estados de São Paulo e Rio de Janeiro, com 24\%. De acordo com o Índice de Cidades Empreendedoras (ICE), da Endeavor (2016), as cidades de São Paulo e Rio de Janeiro constituem os dois maiores polos econômicos do País, ou seja, são Regiões que realizam muitas trocas de bens e serviços com as demais cidades. Em seguida vem Santa Catarina, com $11 \%$.

Outro fator que aponta São Paulo e Rio de Janeiro com maior concentração de bibliotecários empreendedores é que a Região Sudeste reúne a maior quantidade de escolas de Biblioteconomia, tanto privadas quanto públicas, segundo a Associação Brasileira de Educação em Ciência da Informação (2017), somando um total de 17 cursos apenas nessa Região, dos 36 que existem no Brasil. Isso faz com que essa Região tenha mais profissionais formados e que tenham que buscar um diferencial competitivo.

Quanto ao ano de fundação, os resultados apresentam que as empresas foram criadas com maior intensidade a partir do ano de 2009, Governo Lula da Silva. Ainda com relação ao ano de criação das empresas, verifica-se um percentual significativo nos anos de 2009 e 2017, nos dois casos com $13,04 \%$, podendo ser consideradas empresas recentes.

Ao analisar o cenário político e econômico no período de 2009, conforme o Relatório e Parecer Prévio sobre as Contas do Governo da República, realizado pelo Tribunal de Contas da União do Brasil (2010), apesar dos efeitos da crise, a economia brasileira ficou entre os seis melhores do mundo, tendo o Produto Interno Bruto (PIB) brasileiro, em 2009, um dos maiores entre os países do G20. Em relação à taxa de desemprego, ao longo de 2009 , foram criados 995.110 postos de trabalho, um aumento de 3,11\%. Um dos fomentos do governo nessa época, segundo o Caderno de Destaques da Presidência da República do Brasil (BRASIL, 2010), foram as ações e programas, tais como: a melhora no ambiente de negócios e a redução da burocracia por meio da Lei Geral das Micro e Pequenas Empresas e Simples Nacional

Perspectivas em Gestão \& Conhecimento, João Pessoa, v. 9, n. 3, p. 102-129, set./dez. 2019. 
(LCP123/06), a Lei de Registro e Legalização de Empresas e Redesim (Lei 11.598/07), que simplifica processo de registro e legalização de empresas, entre outras iniciativas.

Diante desse cenário, infere-se que o aumento dos postos de trabalho, o desenvolvimento político e econômico e as políticas de fomento do governo, à época, impulsionaram a criação de novas empresas por parte dos bibliotecários. Nessa lógica, a pesquisa do GEM (2010) sobre o Empreendedorismo no Brasil menciona que a atividade empreendedora se elevou em 2009.

A Pesquisa Demográfica das Empresas do Instituto Brasileiro de Geografia e Estatística (IBGE) declara que apesar de ser um ano de crise, houve um aumento na taxa de entrada de empresas em 2009. Das 4,3 milhões de empresas ativas no período, 947,0 mil $(22,2 \%)$ eram recém-criadas. Em contrapartida, foram desativadas 755,2 mil empresas no ano, ou $17,7 \%$ do total. O número mostra um saldo positivo para a criação de empresas no período, com mais registros de entradas do que de saídas do mercado. Logo, a taxa de sobrevivência foi de $77,8 \%$, ou seja, 3,3 milhões das empresas ativas em 2009 eram sobreviventes (INSTITUTO BRASILEIRO DE GEOGRAFIA E ESTATÍSTICA, 2011).

Ao fazer um paralelo do resultado desta pesquisa com o exposto até aqui, infere-se que esses acontecimentos influenciaram os bibliotecários na criação das empresas, embora esses não sejam os únicos fatores para a criação de novas empresas. As motivações para o início da atividade empreendedora são pontos que fazem toda a diferença, uma vez que a decisão do indivíduo na criação de uma empresa é influenciada por uma série de fatores, tais como a experiência, ambiente familiar, contexto social, político e econômico.

Embora o surgimento das empresas seja mais expressivo para a última década, percebe-se que os bibliotecários já estão inseridos nesse universo desde a década de 1980, quando as primeiras empresas na área foram criadas e quando pouco se discutia o empreendedorismo nesse mesmo ambiente profissional.

Quando questionados sobre os serviços, verificou-se uma diversidade de serviços voltados para gestão da informação. Cerca de $12,90 \%$ oferecem gestão de documentos e arquivos, 9,03\% consultoria para elaboração de projetos, 8,39\% organização de bibliotecas, $8,39 \%$ normalização de trabalhos e projetos, $8,06 \%$ realização de cursos e eventos profissionais. Percebe-se que os cinco primeiros serviços mais citados são para atender unidades de informação e os próprios bibliotecários. Uma das hipóteses é que as organizações que não têm um bibliotecário entre seus colaboradores internos contratam esses profissionais para organizar os documentos e o acervo e, por essa razão, esses serviços aparecem com mais evidência. Cabe ressaltar que os bibliotecários não têm explorado outros nichos de atuação ou não estão inovando nos serviços.

Quando perguntados se o empreendimento é formalizado, $80 \%$ das respondentes afirmam que sim, enquanto $20 \%$ declaram que não. Esses empreendedores que não estão formalizadas oferecem produtos e serviços, mas ainda não dispõem de um registro de empresa para emissão de nota fiscal jurídica, pagamento de impostos e garantias de benefícios sociais, como o Instituto Nacional do Seguro Social (INSS). Alguns dos fatores que podem impedir esses trabalhadores de formalizar suas empresas são as regulamentações e a burocracia brasileira, o que faz com que alguns se desmotivem e não arrisquem o negócio no mercado. Segundo o Índice de Cidades Empreendedoras do Endeavor (2017), embora o tempo médio para abertura de uma empresa seja de 62 dias, esse número pode variar muito entre as cidades, devido ao número de licenças, inscrições e alvarás necessários para abrir uma empresa que dependem de prefeituras e juntas comerciais.

No entanto, órgãos como o SEBRAE assessoram as pessoas que desejam formalizar seus negócios. Segundo Teixeira e Almeida (2016), os trabalhadores que formalizam seus negócios passam a contar com alguns benefícios, como: vender ou prestar serviços para grandes empresas, participar de licitações públicas, ter acesso a linhas de crédito com juros

Perspectivas em Gestão \& Conhecimento, João Pessoa, v. 9, n. 3, p. 102-129, set./dez. 2019. 
mais atraentes, maior segurança na contratação de funcionários, redução da inadimplência, pois terá acesso ao Serviço de Proteção ao Crédito (SPC) e Serasa Experian, e ainda maior facilidade nas compras de matérias-primas e produtos para revenda, segurança Jurídica, cobertura previdenciária, maior visibilidade do produto ou prestação de serviço no mercado, entre outras vantagens.

Além dos benefícios da regularização, as empresas com registro formal são responsáveis pela geração de novos empregos. Isso implica que, no caso do bibliotecário, ao prestar de serviços, por exemplo, conforme a demanda de trabalho aumenta, ele tende a contratar colaboradores para conseguir entregar o acordado e no prazo estipulado. Apesar de ser menos de $1 \%$ do total de empresas brasileiras hoje, esses novos empreendimentos são responsáveis por praticamente metade dos novos empregos gerados no País, conforme o Índice de Cidades Empreendedoras criado pela Endeavor (2017).

Em relação ao terceiro objetivo específico desta pesquisa, que buscou verificar a formação empreendedora desses bibliotecários, ao perguntar se o conhecimento adquirido na graduação contribuiu para abrir/manter o seu próprio negócio, $87 \%$ dos respondentes afirmaram que sim, que o conhecimento na formação ajudou no seu negócio e $13 \%$ apontaram que o preparo no curso não foi suficiente para abrir/manter seu próprio negócio. Quando indagados de que forma esse conhecimento contribuiu, os respondentes declararam que a teoria e as técnicas da profissão foram importantes para o desenvolvimento do conhecimento.

Creio que a profissão de bibliotecária me deu todos os instrumentos para atuar em diversos ramos do conhecimento. Sempre há necessidade de profissionais com visão de sistema, capazes de organizar, classificar $e$ indexar dados e as normas de padronização são extremamente úteis para qualquer trabalho. (R13).

A Biblioteconomia dá suporte para atuação em diversas áreas, porque sempre há necessidade de organizar as informações. Assim, tanto as disciplinas técnicas quanto as humanistas ajudaram bastante. (R15).

Creio que a profissão de bibliotecária me deu todos os instrumentos para atuar em diversos ramos do conhecimento. Sempre há necessidade de profissionais com visão de sistema, capazes de organizar, classificar $e$ indexar dados e as normas de padronização são extremamente úteis para qualquer trabalho. (R13).

[...] Todas as disciplinas em geral contribuíram para a criação $e$ desenvolvimento do meu empreendimento, porém destaco duas que foram os pilares principais, que são: Gestão de Serviços de Informação (responsável pela iniciação de ter um olhar empreendedor, estimulação para criação de uma análise crítica de serviços oferecidos em lugares de informação) e a Teoria da Comunicação (analise crítica na construção da informação $e$ comunicação). (R29).

Considerando que os bibliotecários admitem que o conhecimento adquirido na graduação contribuiu para abrir/manter o seu próprio negócio, a próxima pergunta foi: 0 curso de Biblioteconomia poderia ter oferecido algo a mais na formação para facilitar a formação empreendedora, enfrentar desafios e perceber oportunidades? $91 \%$ dos respondentes acreditam que sim, ou seja, que o curso poderia oferecer algo a mais na formação empreendedora e $9 \%$ afirmaram que não. 
A maioria das respostas indica que o curso deveria contribuir para a formação empreendedora, como mencionam os respondentes 15 e 42 ao afirmarem que o curso está preparando os alunos para atuar somente nas bibliotecas e como empregados. Assim, a formação profissional do bibliotecário precisa incluir o ensino do empreendedorismo, de modo a preparar os discentes para atuar também com a prestação de serviços.

Para atingir o quarto objetivo - conhecer as competências empreendedoras -, levantou-se a literatura mediante pesquisa bibliográfica e foi analisada a percepção dos bibliotecários quanto às competências requeridas para empreender.

Foram utilizadas as 10 competências empreendedoras propostas por Cooley (1990) e suas 30 subcategorias de comportamentos para estudar a relação entre essas competências e se os bibliotecários desenvolveram para o fortalecimento de suas atividades empreendedoras, além das perguntas abertas para apontar o que os bibliotecários entendem por competências empreendedoras e se elas se relacionam com suas competências profissionais.

Dessa forma, das competências empreendedoras, as presentes no maior número de bibliotecários são: Comprometimento (COM), com 73,19\% da amostra; Busca de Informações (BDI) - 68,12\%; Persuasão e Rede de Contatos (PRC) - 63,77\%; Persistência (PER), com 63,04\%; Estabelecimento de Metas (EDM) presente em 52,90\% dos bibliotecários; Independência e Autoconfiança (IAC), em 57,97\%; Exigência de Qualidade; Eficiência (EQE), com 59,42\%. Essas foram as competências que se mantiveram na média de $50 \%$ dos bibliotecários que compuseram amostra.

As competências menos presentes nos respondentes foram: Busca de Oportunidade e Iniciativa (BOI), 55\% dos respondentes; Correr Riscos Calculados (CRC) - 49,27\%; e Planejamento e Monitoramento Sistemático (PMS) - 49,28\%. A presença de cada competência foi avaliada a partir da média das três subcategorias.

Quando perguntado aos bibliotecários o que eles entendem por competências empreendedoras, uma parte dos respondentes relacionou as competências empreendedoras com o conhecimento, habilidade e atitude.

A mobilização do conhecimento teórico, habilidades desenvolvidas $e$ percebidas por meio da execução de ações práticas, poder de comunicação, capacidade de articulação pessoal, automotivação e coragem. (R5).

Na minha opinião, competência é caracterizada pelo tripé entre o conhecimento (conteúdo e técnica aprendida), habilidade (forma como fazer, desenvoltura) e atitude (vontade de fazer, força de vontade, ação). (R13).

São todas os seus conhecimentos, habilidades, percepções, sua leitura e interpretação do mundo e de fatos, sua capacidade de planejar, executar, e fazer gestão dos seus objetivos e sonhos. (R19).

Conhecimentos e habilidades adquiridas para tornar um profissional autossuficiente em sua profissão. (R20).

Verifica-se que os bibliotecários entendem que as competências empreendedoras são caracterizadas pelo conjunto de conhecimento, habilidade e atitude (CHA), em conformidade com o visto no referencial teórico, nos autores como Antonello (2005) e Schmitz (2012) que também atribuem o CHA como elemento das competências empreendedoras.

Algumas respondentes entendem por competências empreendedoras a ação de buscar novas oportunidades, de conquistar o mercado, mediante a capacidade de ver as coisas à sua volta e pela identificação de necessidades de um indivíduo ou grupo. Nessa lógica, como

Perspectivas em Gestão \& Conhecimento, João Pessoa, v. 9, n. 3, p. 102-129, set./dez. 2019. 
exposto na literatura, Man, Lau e Chan (2002) também atribuem a competência Oportunidade à identificação, avaliação e busca de oportunidades de negócios e à capacidade de visualizar o ambiente que ampara o processo de decisão, como uma competência empreendedora. Sendo assim, pode-se dizer que as respostas dos sujeitos são compatíveis com o retratado na literatura e, com isso, os bibliotecários entendem o que são as competências empreendedoras.

Considerando que os respondentes conhecem o que são as competências empreendedoras, é preciso identificar se eles relacionam essas competências com as competências da profissão de bibliotecário. Desse modo, foi questionado aos bibliotecários se na sua percepção as competências profissionais do bibliotecário se relacionam com as competências empreendedoras. Dos respondentes, $52 \%$ afirmaram que sim, contra $48 \%$ terem declarado que não, que as competências do bibliotecário não se relacionam com as competências empreendedoras. As que responderam que sim, deveriam responder de que forma elas se relacionam. Dentre as respostas obtidas foram selecionadas as seguintes:

Empreender é uma capacidade que, ao meu ver, possível de se adquirir. Alguns em maior grau outros em menos. Alguns já são mais natos, nessa área. Acredito que em todas as áreas do conhecimento é possivel encontrar características de pessoas inovadoras. Portanto, com a biblioteconomia não seria diferente. O bibliotecário é um dos profissionais da informação. Diante disso, ele precisa usar mais da informação para se valer hora de inovar e empreender. Acredito que ele precisa acreditar mais no seu potencial e fazer valer as suas ideias frente ao mercado e oferecer serviços e produtos de qualidade e que venham de encontro as demandas mercadológicas. (R4).

Acredito que as competências empreendedoras já estão de certo modo implícitas nas competências profissionais do bibliotecário, pois ele deveria possuir essas habilidades e competências para utilizar gerindo com qualidade o espaço em que atua. (R16).

Acredito que as competências profissionais do bibliotecário se relacionam com as competências empreendedoras, mas muitas vezes o bibliotecário não tem essa percepção. Entendo as atividades técnicas dos bibliotecários flertam com as competências empreendedoras. (R19).

É perceptível, por meio das respostas, que os entrevistados relacionam as competências do bibliotecário com as competências empreendedoras por meio do conhecimento (saber) e da habilidade (saber fazer), ou seja, como o profissional articula seus recursos para enfrentar situações de trabalho e de sua vida pessoal.

Ao analisar as competências empreendedoras, percebeu-se que os bibliotecários as conhecem, acreditam que estão relacionadas às competências profissionais, que algumas são mais relevantes do que outras, que é necessário desenvolver algumas delas depois de formado na graduação e que as competências desenvolvidas na graduação não atendem às demandas na área da Gestão da Informação.

Por fim, com base em todas essas informações, elaborou-se um mapa de competências empreendedoras dos bibliotecários. Concluiu-se que, embora os bibliotecários tenham indicado que possuem todas as competências empreendedoras, há uma tendência de que algumas são mais importantes do que outras. As competências Comprometimento, Busca de informações, Persuasão e Rede de contatos e Persistência tiveram maior incidência entre os bibliotecários pesquisados. Infere-se que tais competências podem ser consideradas 
relevantes, por representarem a capacidade dos bibliotecários empreendedores em desempenhar seu trabalho com sucesso, ou seja, satisfação pessoal e profissional.

A capacidade de aproveitar uma oportunidade e transformá-la em um negócio rentável depende de um conjunto de fatores, entre eles o desenvolvimento de competências. Contudo, os bibliotecários que desejam empreender na área da Gestão da Informação podem se deparar com alguns dilemas como, por exemplo, que competências são necessárias para prestar serviços informacionais. Impasses como esse podem influenciar o bibliotecário na identificação de oportunidades e na criação de novas possibilidades.

Dessa forma, o mapa será apresentado na próxima seção e teve a finalidade de relacionar ações que possam fomentar as competências empreendedoras dos bibliotecários. Espera-se que os bibliotecários se sintam instigados a empreender e que possam ser capazes de identificar quais as competências julgam importantes para empreender.

\section{MAPA DE COMPETÊNCIAS EMPREENDEDORAS PARA BIBLIOTECÁRIOS}

Sugere-se que o mapa seja utilizado sob a responsabilidade dos bibliotecários que desejam empreender, considerando que cada indivíduo possa adequá-lo quando for necessário. A capacidade de aproveitar uma oportunidade e transformá-la em um negócio rentável depende de um conjunto de fatores, entre eles o desenvolvimento de competências. Contudo, aos bibliotecários que desejam empreender na área da Gestão da Informação podem se deparar com alguns dilemas como, por exemplo, que competências são necessárias para prestar serviços informacionais. Impasses como esse podem influenciar o bibliotecário na identificação de oportunidades e na criação de novas possibilidades.

Dessa forma, esse mapa tem a finalidade de relacionar ações que possam fomentar as competências empreendedoras dos bibliotecários.

Espera-se, assim, que os bibliotecários se sintam instigados a empreender e que possam ser capazes de identificar quais as competências julgam importantes para empreender. 
Figura 1 - Mapa de competências

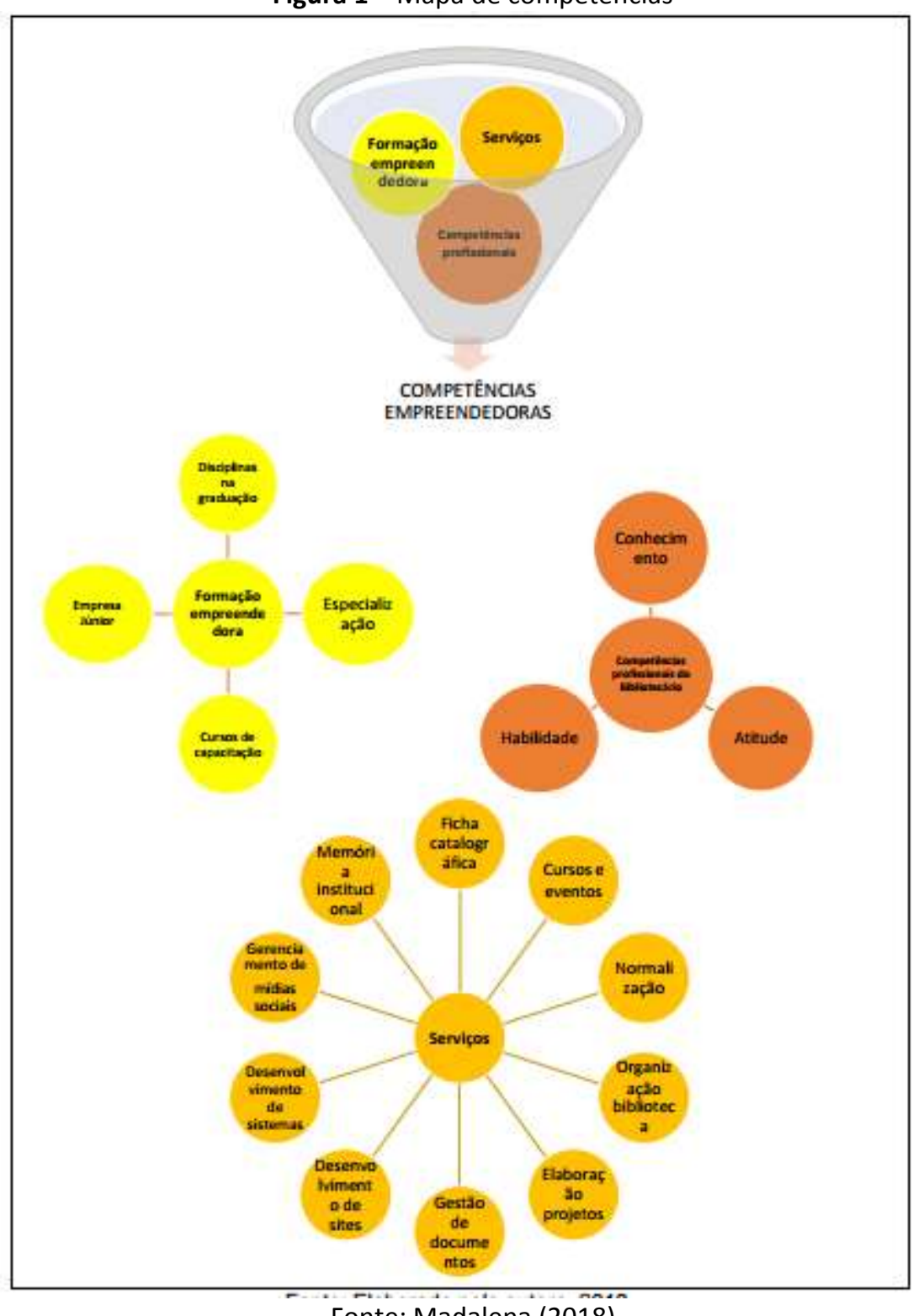

Fonte: Madalena (2018)

A formação empreendedora tende a proporcionar ao bibliotecário conteúdos teóricos e práticas apropriadas para o desenvolvimento das competências empreendedoras. Assim, o Conjunto Formação Empreendedora compreende as seguintes subcategorias: Disciplinas na graduação, Empresa Júnior, Especialização e Cursos de capacitação.

A formação empreendedora pode ser potencializada por meio das disciplinas na graduação, participação na empresa júnior e/ou centro acadêmico, buscando a educação continuada mediante a especialização e cursos de capacitação, entre outras possibilidades. 
Figura 2 - Conjunto Formação Empreendedora

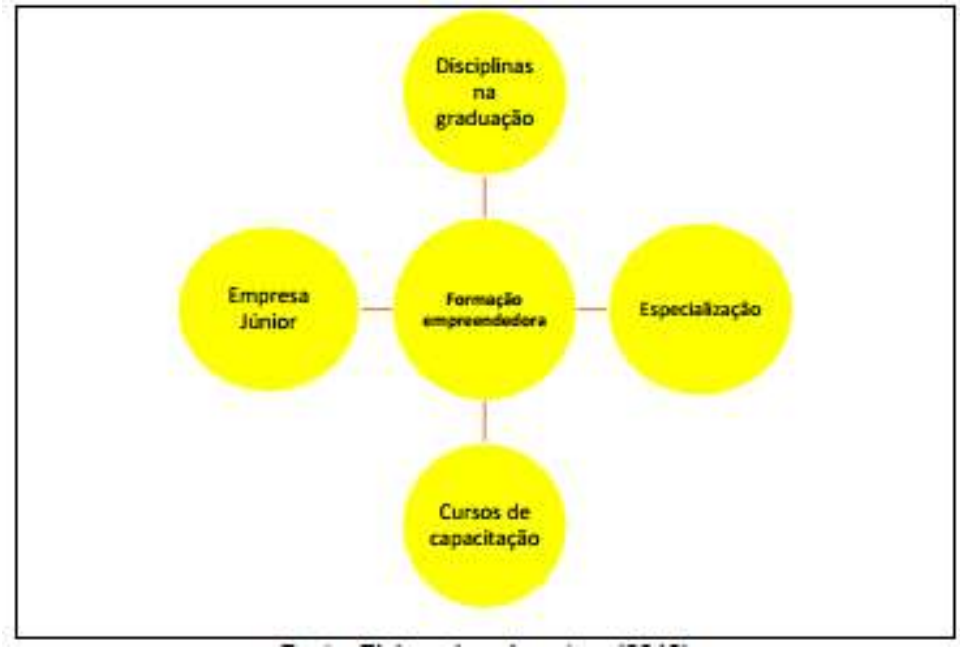

Fonte: Madalena (2018)

As disciplinas na graduação são importantes para o desenvolvimento de conhecimentos teóricos e técnicos relativos à área da Biblioteconomia aliados com a prática de recuperar, disseminar e usar a informação. Por isso, a formação profissional deve contemplar o desenvolvimento de competências para atividades que visam a aquisição teórica e prática próprias da profissão de bibliotecário.

A Empresa Júnior tem o propósito de fomentar o aprendizado prático do estudante em sua área de atuação e possibilitar aos mesmos a oportunidade de aprimoramento técnico mediante à trabalhos, possibilitando-Ihes por exemplo, a resolução de problemas. O Centro Acadêmico também pode influenciar na formação empreendedora, desenvolvendo conhecimentos e habilidades sobre organização de atividades acadêmicas extracurriculares como: realização de projetos de extensão, captação de recursos, busca de parcerias e ações políticas dos estudantes.

Todavia, o conhecimento adquirido ao longo da graduação não é mais suficiente para a atuação do bibliotecário, é importante a educação continuada de acordo com a realidade do mercado de trabalho. Aponta-se alguns cursos de especialização que pode auxiliar na formação empreendedora segundo dados da pesquisa: Administração; Gestão Empresarial; Gestão de Segurança da Informação; Marketing; Empreendedorismo Tecnológico e Comunicação; Gestão de Unidades de Informação; Tecnologias da Informação e Comunicação; Ciência da Informação; Gestão da Informação em Contextos Digitais; Gestão Arquivística, Elaboração de Projetos e Oratória.

Os cursos de capacitação podem acontecer dentro ou fora da universidade, por meio, de seminários nas disciplinas ou projetos de extensão, workshops, oficinas, palestras, cursos, envolvimento em programas de incubadoras de empresas e feiras de empreendedorismo.

Conforme o exposto, a formação empreendedora deve estar baseada no conhecimento e habilidades proporcionadas pelas disciplinas do curso de Biblioteconomia, mas com a complementação de cursos de capacitação e especialização. Logo, o bibliotecário estará melhor preparado para administrar seu próprio negócio com competência e ainda conquistar os resultados esperados e expandir os negócios.

A prestação de serviços depende do conhecimento e habilidade que o bibliotecário tem em relação ao que se propôs vender e por isso integram alguns elementos necessários para a sua construção. Dessa forma, o Conjunto Serviços abrange os principais serviços mencionados nos dados da pesquisa. 
Figura 3 - Conjunto de serviços

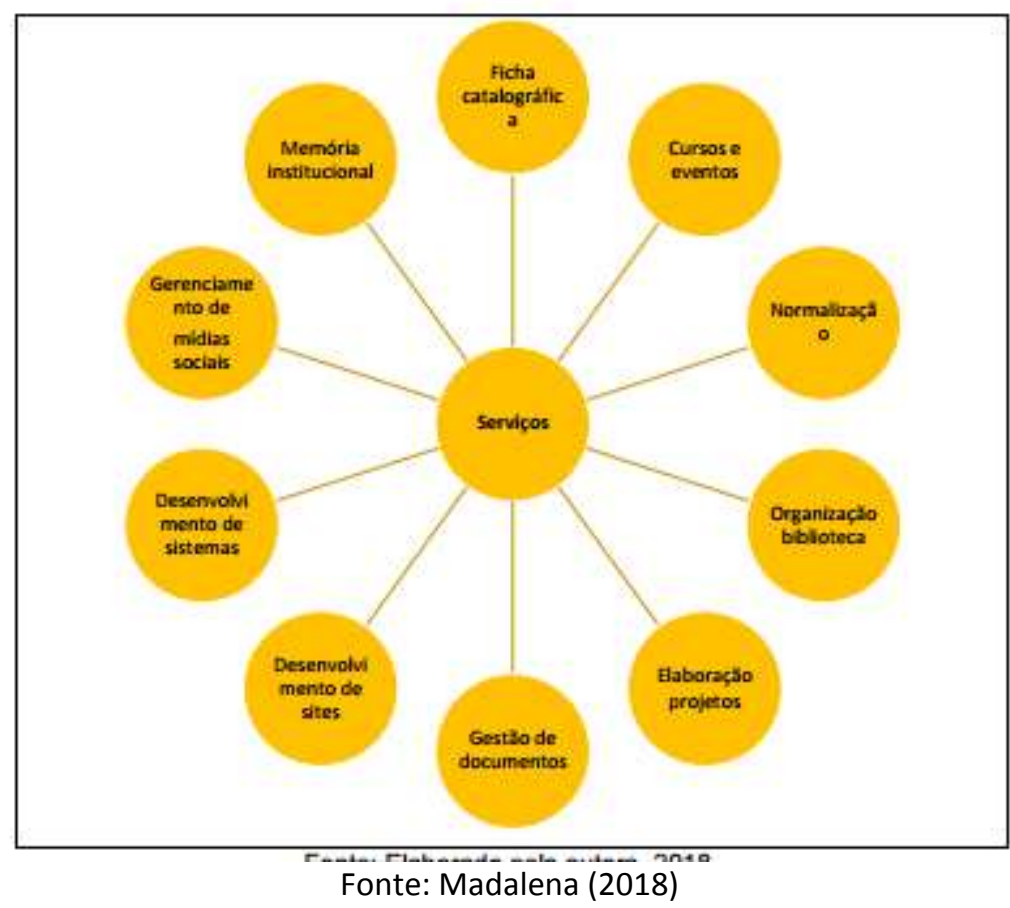

Entre os serviços que podem ser oferecidos pelos bibliotecários de acordo com os dados da pesquisa são: elaboração de ficha catalográfica; realização de cursos e eventos profissionais; normalização de trabalhos e projetos; organização de bibliotecas; consultoria na elaboração de projetos; gestão de documentos físicos e digitais; desenvolvimento de sites pessoais e institucionais; desenvolvimento de sistemas de informação e softwares de gerenciamento de coleções; gerenciamento de conteúdo em mídias sociais e projetos voltados para memória institucional.

Ao prestar serviços na área da gestão da informação deve-se considerar os seguintes aspectos: velocidade na realização dos trabalhos; atendimento personalizado; capacidade de mudança e adaptação; tempo em que o serviço continuará útil para o cliente e se resolve a um problema ou atende a uma necessidade. Outro ponto a ser enfatizado é a equipe, que auxiliará o bibliotecário na prestação de serviços. A equipe pode ser composta pelos seguintes profissionais: Arquivologia; Administração; Comunicação Social; Profissionais de Informática; Design, além de outros profissionais da Biblioteconomia. Esses profissionais precisam ter atribuições relacionadas com o serviço a ser prestado, isto é, ter o profissional certo na função adequada. Além disso, ninguém possui todas as competências necessárias e por isso é interessante requerer outros profissionais.

As competências profissionais são desenvolvidas ao longo da trajetória profissional relacionadas com a formação e ao meio em que se está inserido, devendo ser aperfeiçoadas constantemente. Sabe-se que as competências de um profissional envolvem o conhecimento (saber), a habilidade (saber fazer) e atitude (saber ser), que representam o conjunto de valores peculiares a cada indivíduo. Essas competências são intrínsecas e representam a capacidade de atuação do profissional no mercado de trabalho. 
Figura 4 - Competências profissionais do bibliotecário

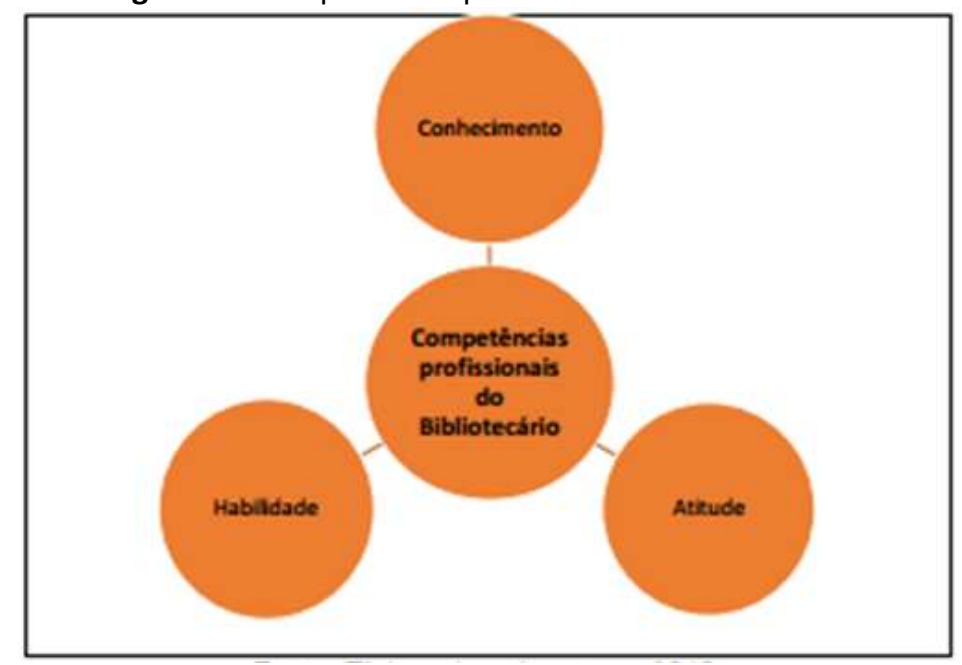

Fonte: Madalena (2018)

Ao relacionar as práticas profissionais do bibliotecário com as demandas de mercado, constata-se o quanto é fundamental considerar as competências (conhecimento, habilidade e atitude) no processo de formação do bibliotecário. Nesse sentido, recomenda-se que o bibliotecário desenvolva posturas e competências compatíveis com as funções biblioteconômicas, de modo, que o possibilite perceber nichos de mercado que carecem de serviços especializados em informação. Em relação ao conhecimento (ao saber) adquirido com as disciplinas na graduação, o bibliotecário deve ter: a) Conhecer as normas e técnicas de padronização de trabalhos (ABNT); b) Conhecer as fontes de informação; conhecer técnicas de pesquisa; c) Interpretar e comunicar a informação; conhecer técnicas de atendimento; d) Conhecer os serviços informacionais; e) Conhecer técnicas gerenciais, entre outros.

No que tange às habilidades (saber-fazer) o bibliotecário deve dar sentido ao conhecimento mediante as suas práticas e técnicas para o desempenho de algumas funções. Com isso o bibliotecário tende a desenvolver habilidades como: a) Saber utilizar os recursos disponíveis; b) Utilizar-se dos saberes para resolver problemas; c) Saber acessar as fontes de informação; d) Produzir serviços e produtos; e) Ser capaz de aprender; f) Saber se comunicar; g) Ser capaz de dominar as técnicas de gestão; h) Saber organizar a informação; i) Saber agregar valor à informação; j) Saber negociar; k) Ser comprometido; I) Ser criativo; m) Pesquisar tendências; $n$ ) Identificar novos nichos; o) Conduzir equipe; p) Identificar demandas e oportunidades, entre outros.

No que se refere a atitude (saber-agir) está associada à ação, vontade e ao comportamento de cada bibliotecário, isto é, o querer fazer. As atitudes envolvem: a) Ter responsabilidade; b) Ter senso crítico; c) Incentivar o trabalho em equipe; d) Ser ético; e) Buscar associações e alianças; f) Entender a demanda e ter proatividade para fazer acontecer; g) Se antecipar às necessidades, entre outros.

A intenção não foi esgotar todas as competências existentes dos bibliotecários, mas de apresentar algumas competências profissionais. A contribuição do empreendedorismo para a formação do bibliotecário consiste na possibilidade de capacitá-lo a desenvolver competências que o possibilite a identificar oportunidades de inserção no mercado e prestar serviços na área de gestão da informação. Logo, o conjunto Competências Empreendedoras é o resultado de todos os outros conjuntos mencionados. 
Figura 5 - Competências empreendedoras

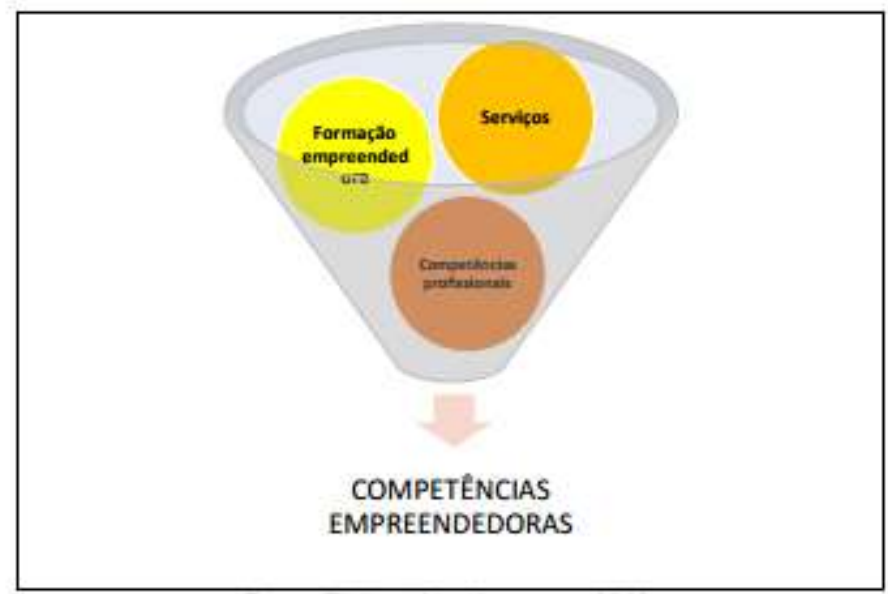

Fonte: Madalena (2018)

Quadro 2 - Principais serviços ofertados por bibliotecários empreendedores no Brasil e respectivas competências esperadas

\begin{tabular}{|c|c|c|}
\hline Serviços & Atitudes & Habilidades e Conhecimento \\
\hline $\begin{array}{l}\text { Gestão de } \\
\text { documentos e } \\
\text { arquivos físicos e } \\
\text { digitais }\end{array}$ & $\begin{array}{l}\text { Ser persistente; Comprometimento; Iniciativa; } \\
\text { Foco na realização serviço de qualidade; Inter- } \\
\text { relacionamento pessoal; Assumir riscos; Pensar } \\
\text { em formas de investir em novas oportunidades } \\
\text { no mercado de trabalho; }\end{array}$ & $\begin{array}{l}\text { Saber encontrar soluções; } \\
\text { Planejamento; Criatividade; Conhecer as } \\
\text { tecnologias; Rede de contatos; } \\
\text { Estabelecimento de metas; } \\
\text { Conhecimento arquivístico e de } \\
\text { mercado; Saber inovar }\end{array}$ \\
\hline $\begin{array}{l}\text { Consultoria na } \\
\text { elaboração de } \\
\text { projetos }\end{array}$ & $\begin{array}{l}\text { Ser persistente; Ter foco; Iniciativa } \\
\text { Comprometimento; Foco na realização serviço } \\
\text { de qualidade; Inter-relacionamento pessoal; } \\
\text { Assumir riscos; Pensar em formas de investir } \\
\text { em novas oportunidades no mercado de } \\
\text { trabalho; }\end{array}$ & $\begin{array}{l}\text { Saber encontrar soluções; Boa } \\
\text { comunicação escrita; Planejamento; } \\
\text { Criatividade; Liderança; Conhecer as } \\
\text { tecnologias; Capacidade de trabalhar em } \\
\text { equipe; Persuasão, Rede de contatos; } \\
\text { Busca de informações; Estabelecimento } \\
\text { de metas; Conhecimento de mercado; } \\
\text { Saber inovar }\end{array}$ \\
\hline $\begin{array}{l}\text { Organização de } \\
\text { bibliotecas }\end{array}$ & $\begin{array}{l}\text { Comprometimento; Iniciativa; Foco na } \\
\text { realização serviço de qualidade; Inter- } \\
\text { relacionamento pessoal; Assumir riscos }\end{array}$ & $\begin{array}{l}\text { Ser organizado; Planejamento; } \\
\text { Criatividade; Conhecer as tecnologias; } \\
\text { Rede de conatos; Estabelecimento de } \\
\text { metas; Saber inovar }\end{array}$ \\
\hline $\begin{array}{l}\text { Normatização de } \\
\text { trabalhos e } \\
\text { projetos }\end{array}$ & $\begin{array}{l}\text { Comprometimento; Iniciativa; Foco na } \\
\text { realização serviço de qualidade; Inter- } \\
\text { relacionamento pessoal; Assumir riscos }\end{array}$ & $\begin{array}{l}\text { Planejamento; Criatividade; Rede de } \\
\text { contatos; Conhecimento em ABNT; } \\
\text { Busca de informações; Estabelecimento } \\
\text { de metas; Saber inovar }\end{array}$ \\
\hline $\begin{array}{l}\text { Realização de } \\
\text { cursos e eventos } \\
\text { profissionais }\end{array}$ & $\begin{array}{l}\text { Comprometimento; Iniciativa; Foco na } \\
\text { realização serviço de qualidade; Inter- } \\
\text { relacionamento pessoal; Assumir riscos; Pensar } \\
\text { em formas de investir em novas oportunidades } \\
\text { no mercado de trabalho; }\end{array}$ & $\begin{array}{l}\text { Boa comunicação verbal; Planejamento; } \\
\text { Criatividade; Conhecer as tecnologias; } \\
\text { Capacidade de trabalhar em equipe; } \\
\text { Rede de contatos; Conhecimento de } \\
\text { mercado e finanças; Saber motivar; } \\
\text { Saber inovar }\end{array}$ \\
\hline $\begin{array}{l}\text { Elaboração de } \\
\text { ficha } \\
\text { catalográfica }\end{array}$ & $\begin{array}{l}\text { Comprometimento; Iniciativa; Foco na } \\
\text { realização serviço de qualidade; Inter- } \\
\text { relacionamento pessoal; Assumir riscos }\end{array}$ & $\begin{array}{l}\text { Conhecer ABNT; Conhecimento } \\
\text { catalogação; Estabelecimento de metas; } \\
\text { Saber inovar }\end{array}$ \\
\hline $\begin{array}{l}\text { Desenvolvimento } \\
\text { de sites pessoais } \\
\text { e institucionais }\end{array}$ & $\begin{array}{l}\text { Comprometimento; Iniciativa; Foco na } \\
\text { realização serviço de qualidade; Inter- } \\
\text { relacionamento pessoal; Assumir riscos; Pensar }\end{array}$ & $\begin{array}{l}\text { Saber encontrar soluções; } \\
\text { Planejamento; Criatividade; Conhecer as } \\
\text { tecnologias; Estabelecimento de metas }\end{array}$ \\
\hline
\end{tabular}

Perspectivas em Gestão \& Conhecimento, João Pessoa, v. 9, n. 3, p. 102-129, set./dez. 2019. 


\begin{tabular}{|l|l|l|}
\hline & $\begin{array}{l}\text { em formas de investir em novas oportunidades } \\
\text { no mercado de trabalho; }\end{array}$ & $\begin{array}{l}\text { Busca de informações; Conhecimento de } \\
\text { mercado; Saber inovar }\end{array}$ \\
\hline $\begin{array}{l}\text { Projetos voltados } \\
\text { para a memória } \\
\text { institucional }\end{array}$ & $\begin{array}{l}\text { Comprometimento; Iniciativa; Foco na } \\
\text { realização serviço de qualidade; Inter- } \\
\text { relacionamento pessoal; Assumir riscos }\end{array}$ & $\begin{array}{l}\text { Boa comunicação escrita; Planejamento; } \\
\text { Criatividade; Conhecer as tecnologias; } \\
\text { Capacidade de trabalhar em equipe; } \\
\text { Rede de contatos; Busca de } \\
\text { informações; Estabelecimento de metas, } \\
\text { Saber inovar }\end{array}$ \\
\hline $\begin{array}{l}\text { Desenvolvimento } \\
\text { de sistemas de } \\
\text { informação e } \\
\text { softwares de } \\
\text { gerenciamento } \\
\text { de coleções }\end{array}$ & $\begin{array}{l}\text { Comprometimento; Iniciativa; Foco na } \\
\text { realização serviço de qualidade; Inter- } \\
\text { relacionamento pessoal; Assumir riscos; Pensar } \\
\text { em formas de investir em novas oportunidades } \\
\text { no mercado de trabalho; }\end{array}$ & $\begin{array}{l}\text { Saber encontrar soluções; Conhecer as } \\
\text { tecnologias Planejamento; Criatividade; } \\
\text { informações; Estabelecimento de metas; } \\
\text { Conhecimento de mercado, Saber inovar }\end{array}$ \\
\hline $\begin{array}{l}\text { Gerenciamento } \\
\text { de conteúdo em } \\
\text { mídias sociais }\end{array}$ & $\begin{array}{l}\text { Comprometimento; Iniciativa; Inter- } \\
\text { relacionamento pessoal; Assumir riscos; Pensar } \\
\text { em formas de investir em novas oportunidades } \\
\text { no mercado de trabalho; }\end{array}$ & $\begin{array}{l}\text { Boa comunicação escrita; Planejamento; } \\
\text { Criatividade; Conhecer as tecnologias; } \\
\text { Rede de contatos; Busca de } \\
\text { informações; Estabelecimento de metas; } \\
\text { Saber inovar }\end{array}$ \\
\hline
\end{tabular}

Fonte: Madalena (2018)

O processo de desenvolvimento de competências é resultante do conhecimento e da personalidade por meio da vivência de experiências significativas e de atividades pedagógicas concebidas e planeadas no decorrer da formação profissional.

Os currículos dos cursos de Biblioteconomia demonstram que ainda são poucas as instituições que ofertam disciplinas sobre empreendedorismo. Contudo as que oferecem, tentam abordar questões teóricas como fundamentos e conceitos do empreendedorismo, perfil empreendedor, o bibliotecário empreendedor e plano de negócios. De fato, são temas importantes pois possibilitam o discente a desenvolver competências como o conhecimento sobre o universo empreendedor. Porém, esse conhecimento deve ser expandido, não se limitando apenas nos conhecimentos da profissão, o conhecimento sobre administração, mercado, estratégias, finanças, gestão de pessoas podem contribuir para alcançar as metas e objetivos. No entanto, percebe-se que para desenvolver e aprimorar esse conhecimento, deve-se buscar por cursos, treinamentos, palestras, workshop e especialização, ou seja, procurar uma formação complementar de modo a adquirir novas competências.

Alguns cursos que oferecem disciplinas de empreendedorismo, tem um foco mais prático, apresentando práticas de consultoria aplicáveis em ambientes informacionais, a disponibilização de serviços de informação, elaboração e seleção de projetos, serviços e produtos de informação para negócios, execução do plano de negócio para empresas prestadoras de serviços de informação e desenvolvimento da capacidade empreendedora. Nota-se que algumas instituições de ensino consideram essas práticas instrumentos imprescindíveis para o desenvolvimento de competências como a autonomia, a trabalhar por meio de problemas, criar ou reformular novos serviços, a desenvolver projetos, ou seja, defendem a integração do indivíduo nos saberes teóricos e práticos.

Vale destacar a iniciativas dessas instituições em estar aliando a teoria e a prática, dando a cada estudante uma maior experiência e tornando-os capazes de serem prestadores de serviços de informação. Em se tratando de práticas, ressaltasse que a universidade também é fundamental no desenvolvimento de algumas habilidades que colaboram na prestação de serviços. Destaca-se tais habilidades: trabalhar em equipe, saber planejar, saber motivar, saber resolver problemas, conhecer as tecnologias, ser criativo, saber se comunicar, desenvolver uma rede de contatos, saber buscar a informação, estabelecer metas, saber inovar, entre

Perspectivas em Gestão \& Conhecimento, João Pessoa, v. 9, n. 3, p. 102-129, set./dez. 2019. 
outras.

Essas habilidades podem ser aprimoradas com experiências vividas na prática, pois estas demonstram como cada indivíduo tem habilidade para vivenciar cada situação. Essa vivência pode ser estimulada em sala de aula, com trabalhos que favorecem a autonomia e a independência assim como a participação em centro acadêmico e empresa júnior.

Atualmente existem no país oito empresas juniores de Biblioteconomia, Arquivologia e Ciência da Informação, número considerado pequeno se considerar a importância dessa prática para o desenvolvimento do espírito empreendedor dos alunos. Essas ações proporcionam o discente a lidar com situações de seu cotidiano e ser capaz de resolver problemas reais, é uma oportunidade para aqueles que desejam ter um negócio vivenciar a rotina de uma empresa.

No que diz respeito à atitude, a formação acadêmica ainda não consegue abranger tal desenvolvimento, se considerarmos o referencial teórico dessa pesquisa, observa-se que são poucas as atividades pedagógicas realizadas. Assim, deve-se repensar o desenvolvimento das disciplinas dos cursos, dando foco tanto no conhecimento teórico, nas habilidades, mas também com ênfase nas atitudes.

Dentre as atitudes que se julga importante para a prestação de serviços de informação estão: persistência, comprometimento, iniciativa, foco na realização serviço de qualidade, inter-relacionamento pessoal, assumir riscos e pensar em formas de investir em novas oportunidades no mercado de trabalho.

Percebe-se que a atitude é a competência que mais depende da iniciativa daquele que deseja ser um prestador de serviço, pois ele precisa realmente fazer para conhecer e adquirir a experiência necessária. Contudo, para desenvolver estas atitudes é necessário que se estimule esse desenvolvimento ainda durante a formação profissional, mas que também sempre busque investir no aprimoramento. Portanto, as competências é que caracterizam cada indivíduo, esse diferencial é que torna cada profissional apto a enfrentar as dificuldades do mercado de trabalho.

Entende-se que há diversos estudos sobre a formação acadêmica em Biblioteconomia, mas, são poucos os que têm um olhar mais atento para a formação empreendedora dos bibliotecários. Acredita-se que as instituições de ensino superior se esforçam para desenvolver e aplicar, nas práticas pedagógicas as competências necessárias para a atuação do profissional do bibliotecário como empreender no mercado de trabalho. Mas, é fundamental que o bibliotecário procure por uma educação continuada para ser manter atualizado.

As exigências do mercado, a formação em Biblioteconomia, a educação continuada com a especialização e os cursos de capacitação, além do desenvolvimento das competências requeridas para o exercício profissional, são fatores que inter-relacionados propiciam o fortalecimento das competências empreendedoras.

As competências e atuação do bibliotecário precisam transpor as diversas áreas do conhecimento, com múltiplas habilidades para lidar com a informação e principalmente com atitudes que o tornem um bibliotecário empreendedor diferenciado, atuante, dinâmico, participativo e capaz de dar respostas rápidas e adequadas ao mercado.

Em suma, o desenvolvimento da competência empreendedora se faz necessário sob um perfil de reflexões, num âmbito do saber ser, das práxis e das relações. A expansão dessas competências é delineada por fatores-chaves como: o investimento em formação, novos aprendizados, na construção do conhecimento por meio das experiências, buscam de habilidades técnicas e gerenciais e desenvolvimento de comportamentos adequados.

\section{BREVES CONSIDERAÇÕES}

A atuação do bibliotecário está cada vez menos limitada às bibliotecas, no entanto,

Perspectivas em Gestão \& Conhecimento, João Pessoa, v. 9, n. 3, p. 102-129, set./dez. 2019. 
poucos atuam em outros campos, o que se caracteriza em um desafio manter-se no mercado de trabalho, que está cada vez mais exigente e competitivo. Dessa forma, é preciso constantemente aprimorar os conhecimentos e desenvolver novas habilidades técnicas e pessoais para atender as necessidades do mercado. Os profissionais precisam demonstrar proatividade, criatividade, inovação, manter-se atualizados, liderar e trabalhar em equipe e desenvolver a capacidade de identificar oportunidades em novos contextos.

Diante disso, o empreendedorismo surge como uma nova postura e visão para o mundo de trabalho, ou seja, o empreendedor é um profissional que mediante suas características pessoais e comportamentos é capaz de identificar novas oportunidades para inovar. Nesse contexto, encontram-se os bibliotecários que estão empreendendo na prestação de serviços de informação.

Contudo, a necessidade de adquirir e desenvolver certas competências é cada vez maior e está presente no mundo do trabalho. Por isso, acredita-se que a formação empreendedora dentro e fora da universidade pode auxiliar os bibliotecários no desenvolvimento dessas competências. Essa formação pode ocorrer por meio das disciplinas ministradas os cursos de graduação, de participação na empresa júnior e centro acadêmico de curso de especialização, de cursos de capacitação, entre outras iniciativas.

Em relação ao primeiro objetivo específico, referente a conhecer as competências empreendedoras segundo a literatura, buscou-se compreender quais são as competências comuns entre os empreendedores de sucesso. Para construir tal base conceitual, realizou-se uma pesquisa bibliográfica, resgatando os conceitos sobre competências empreendedoras para verificar e selecionar pesquisas que contemplassem essa temática. Constatou-se não haver até o momento uma pesquisa sobre o objeto de pesquisa aqui abordado; o que se encontrou foram pesquisas que tratavam das competências empreendedoras de professores, administradores, hoteleiros e profissionais do secretariado executivo. Para analisar as competências empreendedoras, adotou-se o modelo desenvolvido por Cooley (1990) como modelo conceitual de pesquisa para as competências empreendedoras.

O segundo objetivo específico, que buscou identificar bibliotecários que têm empresas no Brasil e quais são os serviços ofertados, foi realizado por meio do mapeamento via entidades de classe, tais como associações, conselhos e sindicatos de bibliotecários. No período investigado, localizaram-se 55 empresas criadas por bibliotecários no Brasil, com um total de 60 bibliotecários, mas apenas 46 proprietários dessas empresas participaram dessa pesquisa.

Ao analisar os tipos de serviços ofertados por empresas criadas por bibliotecários foi possível verificar que atendem diferentes demandas, nos mais variados campos de atuação. No entanto, a pesquisa não aprofundou em saber o grau de inovação, valor agregado dos serviços e nem métricas de desempenho, métodos, tecnologias ou mesmo processos utilizados para criação e oferta dos serviços, ficando como sugestão para futuras pesquisas.

No entanto, nota-se que os bibliotecários não estão pensando diferente, ou seja, não estão sendo visionários, não estão enxergando as coisas que acontecem a sua volta e dessa forma não estão fazendo a diferença, apenas estão desenvolvendo serviços que outras profissionais da área também ofertam; isso significa que só pensam na realidade dos próprios bibliotecários, sendo que há inúmeros problemas de outras áreas a serem resolvidos. Infere-se que uma solução para esse problema é melhorar o marketing pessoal, focar em outros usuários, ampliar o networking, assumir risco em propor um novo serviço ou prospectar clientes potenciais e observar as tendências de mercado.

O terceiro objetivo específico buscou verificar a formação empreendedora dos bibliotecários por meio da revisão de literatura, projetos pedagógicos dos cursos de graduação e análise dos resultados dos questionários respondidos. Nem todos os cursos de Biblioteconomia disponibilizam o projeto pedagógico no site da instituição, mas com base na

Perspectivas em Gestão \& Conhecimento, João Pessoa, v. 9, n. 3, p. 102-129, set./dez. 2019. 
verificação nos sites de cursos para analisar a ementa, percebe-se que dos 36 cursos presenciais de Biblioteconomia (com turmas vigentes), 55\% não tem nenhuma disciplina voltada para o empreendedorismo.

A formação empreendedora ainda pode ser desenvolvida por meio de cursos de especialização e cursos de capacitação para aprimorar e desenvolver as competências profissionais e adequar-se às novas demandas da sociedade e do mercado. A formação empreendedora, em geral, pode auxiliar os bibliotecários a desenvolver o comportamento que vá ao encontro de conhecimentos, habilidades e atitudes necessários a um empreendedor e que o tornem capaz de descobrir uma oportunidade, planejar e abrir um novo negócio, ser visionário, assumir riscos, persistir, lidar com conflitos, ser criativo, aprender com a tomada de decisão, erros e acertos, trabalhar em equipe, formar uma rede de contatos e ser comprometido com o negócio.

O quarto objetivo específico visou apresentar a percepção dos bibliotecários quanto às competências requeridas para empreender. Essa análise foi feita com base nas respostas dos questionários e com a aplicação do Modelo Conceitual de Cooley (1990). Foi possível verificar que os bibliotecários pesquisados possuem todas as competências empreendedoras: busca de oportunidades e iniciativas, correr riscos calculados, exigência de qualidade e eficiência, persistência, comprometimento, busca de informações, estabelecimento de metas, planejamento e monitoramento sistemático, persuasão e rede de contatos e independência e autoconfiança. Contudo, as competências comprometimento, busca de informações, persuasão e rede de contatos e persistência tiveram maior incidência entre os bibliotecários pesquisados. Infere-se que tais competências podem ser consideradas relevantes, por representarem a capacidade dos bibliotecários empreendedores em desempenhar seu trabalho com sucesso, ou seja, satisfação pessoal e profissional. Isso significa que o comprometimento e a persistência se referem aos esforços que os bibliotecários pesquisados dedicam para realizar suas atividades da melhor forma, com seus clientes, colaboradores, fornecedores, mas acima de tudo, por estarem comprometidos com suas ideias e propósitos, de modo a agir para cumprir com o que foi acordado mesmo frente aos obstáculos.

As competências planejamento e monitoramento sistemático, correr riscos calculados, busca de oportunidade e de iniciativa tiveram menor destaque e foram consideradas minoria entre as pesquisadas. Desse modo, um dos aspectos que se poderia considerar para esse resultado é que os bibliotecários empreendedores parecem agir antes de planejar, ou seja, estão mais preocupadas em fazer, o que parece indicar que elas agem antes de refletir e planejar.

Foi criado um mapa de competências empreendedoras para bibliotecários com base na análise dos dados, bem como da literatura. O mapa tem a finalidade de promover maior compreensão a respeito dos conhecimentos, habilidades e atitudes que devem ser desenvolvidas pelo profissional para a o desenvolvimento das competências empreendedoras. Sua contribuição para a área, assim como aos bibliotecários que querem empreender, é que o mapa facilitará o entendimento acerca do que vem a ser o empreendedorismo no âmbito da formação e atuação dos bibliotecários e possibilitará aos docentes do curso de Biblioteconomia conhecer a abrangência e a importância do ensino do empreendedorismo no âmbito da Universidade, de modo a definir metodologias mais adequadas para o ensino.

De modo geral, observa-se que o entendimento das competências empreendedoras é inerente a um tipo de personalidade e ao comportamento resultante dessa característica, que leva um indivíduo a desenvolver certas atividades. A presença de competências norteia mudanças de comportamento e mostra o quanto é importante ter a consciência e responsabilidade com a formação dos bibliotecários. Compreende-se, desse resultado, que o bibliotecário fazendo uso apropriado de suas competências, pode ter mais percepções estratégicas, contribuir para o crescimento da empresa e melhoria da prestação dos serviços e

Perspectivas em Gestão \& Conhecimento, João Pessoa, v. 9, n. 3, p. 102-129, set./dez. 2019. 
produtos, ampliando sua atuação para além das bibliotecas.

\section{REFERÊNCIAS}

ALMEIDA, G. O; ZOUAIN, D. M. Mapeamento da literatura sobre empreendedorismo: uma abordagem bibliométrica. Biblionline, João Pessoa, v. 12, n. 2, p. 53-67, 2016.

ANTONELLO, C. S. A metamorfose da aprendizagem organizacional: Uma revisão crítica. In: RUAS, R. L.; ANTONELLO, C. S.; BOFF, L. H. e colaboradores. Os novos horizontes da gestão: aprendizagem organizacional e competências. Porto Alegre: Bookman, 2005.

ALVES, L. A. N.; DAVOK, D. F. Empreendedorismo na área de biblioteconomia: análise das atividades profissionais do bibliotecário formado na UDESC. Revista ACB: Biblioteconomia em Santa Catarina, v. 14, n. 1, p. 313-330, 2009.

ASSOCIAÇÃO BRASILEIRA DE EDUCAÇÃO EM CIÊNCIA DA INFORMAÇÃO (ABECIN). Cursos. Disponivel em: http://www.abecin.org.br/cursos/. Acesso em: 05 abr. 2018.

AZEVEDO, C. E. F. et al. A estratégia de triangulação: objetivos, possibilidades, limitações e proximidades com o pragmatismo. In: ENCONTRO DE ENSINO E PESQUISA EM ADMINISTRAÇÃO E CONTABILIDADE, IV, 2013, Brasília. Anais [...]. Brasília: ANPAD, 2013. Disponível em: http://www.anpad.org.br/admin/pdf/EnEPQ5.pdf. Acesso em: 05 jul. 2018.

BAGGIO, A. F.; BAGGIO, D. K. Empreendedorismo: conceitos e definições. Rev. de Empreendedorismo, Inovação e Tecnologia, v. 1, n. 1, p. 25-38, 2014.

BAPTISTA, S. G. Bibliotecário autônomo versus institucionalizado: carreira, mercado de trabalho e comprometimento organizacional, 1998. Tese (Doutorado em Ciência da Informação) - Universidade de Brasília, 1998.

BARDIN, L. Análise de conteúdo. São Paulo: Edições 70, 2011.

BARON, R. A.; SHANE, S. A. Empreendedorismo: uma visão do processo. São Paulo: Cengage Learning, 2010.

BERNARDES, J. F.; BLATTMANN, U. Empreendedor no ambiente da informação. Ágora, v. 21, n. 42, 2011.

BEZERRA, F. M. P. Empreendedorismo na biblioteconomia em tempos de conexões digitais: o caso da marca t-shirts mural. Revista Brasileira de Biblioteconomia e Documentação, v. 11, 2015.

BRASIL. Lei complementar no 123, de 14 de dezembro de 2006. Institui o Estatuto Nacional da Microempresa e da Empresa de Pequeno Porte. Diário Oficial da república Federativa do Brasil. Brasília, DF, 15 dez. 2006.2 Disponível em: http://www.planalto.gov.br/ccivil 03/LEIS/LCP/Lcp123.htm. Acesso em: 05 abr. 2018. 
BRASIL. Lei complementar no 123, de 14 de dezembro de 2007. Estabelece diretrizes e procedimentos para a simplificação e integração do processo de registro e legalização de empresários e de pessoas jurídicas, cria a Rede Nacional para a Simplificação do Registro e da Legalização de Empresas e Negócios - REDESIM. Diário Oficial da república Federativa do Brasil. Brasília, DF, 04 dez. 2007. Disponível em: http://www.planalto.gov.br/ccivil 03/ Ato20072010/2007/Lei/L11598.htm. Acesso em: 05 abr. 2019.

BRASIL. Presidência da República. Destaques e ações e programas do Governo Federal, nov./dez. 2010. Brasília: Secretaria de Comunicação Social, 2010. Disponível em: http://acervopresidencial.institutolula.org/?p=4691. Acesso em: 05 abr. 2019.

CANDIDO, A. C.; VIANNA, W. B.; BEDIN, S. P. M. Aportes conceituais de empreendedorismo e inovação para o desenvolvimento do profissional da informação em novos contextos de trabalho. In: ENCONTRO NACIONAL DE PESQUISA EM CIÊNCIA DA INFORMAÇÃO, Salvador, 2016. Anais eletrônico [...]. http://www.ufpb.br/evento/lti/ocs/index.php/enancib2016/enancib2016/paper/viewFil e/4065/2482. Acesso em: 05 abr. 2019.

COOLEY, L. Entrepreneurship training and the strengthening of entrepreneurial performance. Final Report. Contract. Washington DC: USAID, 1990.

DALPIAN, J.; FRAGOSO, J. G. R.; ROZADOS, H. B. F. Perfil empreendedor do profissional da informação. Revista Brasileira de Biblioteconomia e Documentação, v. 3, n. 1, p. 99-115, 2007.

DEGEN, R. J. 0 empreendedor: fundamentos da iniciativa empresarial. São Paulo: Markon Books, 2005.

DOLABELA, Fernando. O segredo de Luísa. São Paulo: Cultura, 2006.

DOLABELA, Fernando. Oficina do empreendedor. Rio de Janeiro: Sextante, 2008.

DORNELAS, J. C. Empreendedorismo: transformando ideias em negócios. 3. ed, Rio de Janeiro: Elsevier, 2008.

ENDEAVOR. Índice de cidades empreendedoras. São Paulo, 2016. Disponível em: https://d335luupugsy2.cloudfront.net/cms\%2Ffiles\%2F6588\%2F1479379347ICE+2016++Links+V1.pdf. Acesso em: 5 nov. 2018.

ENDEAVOR. Índice de cidades empreendedoras. São Paulo, 2017. Disponível em: https://d335luupugsy2.cloudfront.net/cms\%2Ffiles\%2F6588\%2F1479379347ICE+2016++ Links+V1.pdf. Acesso em: 05 nov. 2018.

FILION, L. J. Empreendedorismo: empreendedores e proprietários-gerentes de pequenos negócios. Revista de Administração. São Paulo, v. 34, n. 2, p.5-28, abr/jun., 1999. Disponível em: http://www.spell.org.br/documentos/ver/18122/empreendedorismo--empreendedorese-proprietarios-gerentes-de-pequenos-negocios. Acesso em: 10 abr. 2019.

FLEURY, M. T. L.; FLEURY, A. Construindo o conceito de competência. Revista de Administração Contemporânea, Rio de Janeiro, v. 2, n. Especial, p. 183-196, 2001.

Perspectivas em Gestão \& Conhecimento, João Pessoa, v. 9, n. 3, p. 102-129, set./dez. 2019. 
FONSECA, F. B. J. L.; FONSECA, F. M. L.; FONSECA, N. D. L. Ruptura de paradigmas biblioteconômicos, autoformação e mercado de trabalho: estudo de caso. Revista ACB: Biblioteconomia em Santa Catarina, v. 10, n. 2, p. 207-223, 2005.

FONSECA, S. D.; MOTA, F. R. L. O empreendedorismo no contexto da formação do bibliotecário da universidade federal de alagoas. Ciência da Informação em Revista, v. 3, n. 2, 2016.

GLOBAL ENTREPRENEURSHIP MONITOR (GEM). Empreendedorismo no Brasil 2016. Curitiba: IBQP, 2017.

HASHIMOTO, M. Espírito empreendedor nas organizações: aumentando a competitividade através do intraempreendedorismo. São Paulo: Saraiva. 2006.

HISRICH, R. D.; PETERS, M. P. Empreendedorismo. 5. ed. Porto Alegre: Bookman, 2004.

INSTITUTO BRASILEIRO DE GEOGRAFIA E ESTATÍSTICA (IBGE). Demografia das empresas 2009. Brasília, $2011 . \quad$ Disponível em: https://ww2.ibge.gov.br/home/presidencia/noticias/imprensa/ppts/000000057219091920111 94313140153.pdf. Acesso em: 05 abr. 2018.

LAPOLLI, E. M.; ROSA, S. B.; FRANZONI, A. M. B. (org.). Competência empreendedora. Florianópolis: Pandion, 2009. p. 133-150.

LE COADIC, Y. F. A ciência da informação. 2. ed. rev. e atual. Brasília: Briquet de Lemos, 2004.

LENZI, F. C. Os empreendedores corporativos nas empresas de grande porte: um estudo da associação entre tipos psicológicos e competências empreendedoras. 2008. 126 f. Tese (Doutorado em Administração) - Universidade de São Paulo, São Paulo, 2008.

LOPES, R. M. A.; LIMA, E. O.; NASSIF, V. M. J. Panorama sobre a educação para o empreendedorismo. In: LOPES, R. M. A. (Org.). Ensino de empreendedorismo no Brasil: panorama, tendências e melhores práticas. Rio de Janeiro: Alta Books, 2017.

MADALENA, Críchyna da Silva. Competências empreendedoras para a prestação de serviços de informação por bibliotecários no Brasil. Florianópolis, 2018. 209 f. Dissertação (Mestrado em Gestão de Unidades de Informação) - Universidade do Estado de Santa Catarina, Florianópolis, 2018.2 Disponível em: http://www.faed.udesc.br/arquivos/id submenu/3015/crichyna da silva madalena.pdf. Acesso em: 10 fev. 2019.

MAN, T. W. Y.; LAU, T.; CHAN, K. F. (2002, March). The competitiveness of small and medium enterprises: a conceptualization with focus on entrepreneurial competencies. Journal of Business Venturing, v.17, n. 2, p. 123-142, 2002. Disponível em: https://www-sciencedirectcom.ez74.periodicos.capes.gov.br/science/article/pii/S0883902600000586. Acesso em: 3 out. 2018.

MARCHIORI, P. Z. A ciência e a gestão da informação: compatibilidades no espaço profissional. Revista Ciência da Informação, Brasília, v. 31, n. 2, p. 72-79, maio/ago., 2002. 
MCCLELLAND, D. C. The achieving society. Princeton, New Jersey: Van Nostrand, 1961.

MILANO, M. C. D.; DAVOK, D. F. Consultor de informação: serviços prestados Por empresas de consultoria nas áreas de Biblioteconomia e gestão da informação. Revista ACB, Florianópolis, v.14, n.1, p.253-278, jan./jun., 2009.

MINARELLI, J. A. Empregabilidade: o caminho das pedras. 16. ed. São Paulo: Gente, 1995.

PEREIRA, V. F. R. O bibliotecário no comércio eletrônico: o surgimento de um novo campo de atuação. 2014. 72 f. Trabalho de conclusão (Curso de Biblioteconomia) - Escola de Biblioteconomia, Universidade Federal do Estado do Rio de Janeiro, Rio de Janeiro, 2014.

PINHEIRO, A. A. S. P.; FRANCO, E. R. C.; GRAÇA, M. C. Q. Bibliotecário autônomo: uma nova perspectiva. Revista de Biblioteconomia de Brasília, v. 15, n. 1, p. 95-108, 1987.

RABAGLIO, M. O. Seleção por competência. 5. ed. São Paulo: Educador, 2001.

RODRIGUES, K. M. Bibliotecários autônomos: novas práticas de mediação para o acesso à informação e à leitura. 2014. Trabalho de Conclusão- (Curso de Biblioteconomia) Universidade Federal do Rio Grande do Sul, Porto Alegre, 2014.

ROMEIRO, N.; SPUDEIT, D. A formação do bibliotecário empreendedor com foco na gestão de serviços de informação. In: SPUDEIT, Daniela (Org.). Empreendedorismo na biblioteconomia. Rio de Janeiro: Agência Biblioo. 2016. p. 94-112.

SANTA ANNA, J.; PEREIRA, G. Ampliando o campo de atuação bibliotecária: o bibliotecário como consultor informacional. Revista ACB, Florianópolis, v. 19, n. 2, p. 163-173, set. 2014. Disponível em: https://revista.acbsc.org.br/racb/article/view/956. Acesso em: 8 abr. 2019.

SCHMITZ, A. L. F. Competências empreendedoras: os desafios dos gestores de instituições de ensino superior como agentes de mudanças. 2012. Tese (Doutorado em Engenharia e Gestão do Conhecimento) - Universidade Federal de Santa Catarina, Florianópolis, 2012.

SILVA, L. S.; SALES, F. O bibliotecário: atuação profissional em empresas da grande Florianópolis. Revista ACB, Florianópolis, v. 17, n. 2, p. 400-421, set. 2012. Disponível em: https://revista.acbsc.org.br/racb/article/view/798. Acesso em: 08 abr. 2019.

SILVEIRA, J. P. B. Formação empreendedora nos currículos de biblioteconomia na região sul do Brasil. Biblionline, João Pessoa, v. 8, n. 1, p. 32-41, 2012.

SOUZA, V. A. B. Competências empreendedoras no processo de formação do extensionista rural. 2013. 254 p. Tese (Doutorado em Engenharia e Gestão do Conhecimento) - Centro Tecnológico, Universidade Federal de Santa Catarina, Florianópolis, 2013.

SPUDEIT, D. (Org.). Empreendedorismo na Biblioteconomia. Rio de Janeiro: Agência Biblioo, 2016.

SPUDEIT, Daniela et al. Formação para o empreendedorismo nos cursos de licenciatura e bacharelado em Biblioteconomia, Ciência da Informação e Gestão da Informação no Brasil. Perspectivas em Gestão \& Conhecimento, João Pessoa, v. 9, n. 1, p. 232-247, jan./abr. 2019.

Perspectivas em Gestão \& Conhecimento, João Pessoa, v. 9, n. 3, p. 102-129, set./dez. 2019. 
TEIXEIRA, P. R.; ALMEIDA, W. S. S. de. Abertura de uma empresa: aspectos legais e gerenciais. In: SPUDEIT, D. (Org.). Empreendedorismo na biblioteconomia. Rio de Janeiro: Agência Biblioo. 2016. p. 59-75.

TRIBUNAL DE CONTAS DA UNIÃO. Relatório e parecer prévio sobre as contas do Governo da República. 2010.2 Disponível em: https://portal.tcu.gov.br/tcu/paginas/contas governo/contas 2009/Textos/CG\%202009\%20R elat\%C3\%B3rio.pdf.Acesso em: 05 abr. 2019.

VALENTIM, M. L. P. Profissional bibliotecário e as perspectivas socioeconômicas neste final de século. In: ENCUENTRO DE DIRETORES, DOCENTES SW LAS ESCUELAS DE BIBLIOTECOLOGIA DEL MERCOSUR, 2, Chile, Oct. 1998. Anais eletrônicos [...]. Santiago, 1998. P. 109-114. Disponível em: http://utem.cl/deptogestinfo/21.doc. Acesso em: 04 abr. 2019.

VALENTIM, M. L. P. et al. Grupos de pesquisa como espaço de construção e compartilhamento de conhecimento. In: ENCONTRO NACIONAL DE PESQUISA EM CIÊNCIA DA INFORMAÇÃO, 12, 2011, Brasília. Anais eletrônico [...]. Brasília: UNB, 2011. Disponível em: http://enancib.ibict.br/index.php/enancib/enancibXII/paper/view/820.. Acesso em: 01 abr. 2019

YANO, N. M.; MONTEIRO, S. M. M. Mudanças institucionais na década de 1990 e seus efeitos sobre a produtividade total de fatores. In: ENCONTRO NACIONAL DE ECONOMIA, 36., 2008, Salvador. Anais [...]. Salvador, 2008. Disponível em: http://www.anpec.org.br/encontro2008/artigos/200807211610100-.pdf. Acesso em: 20 nov. 2018. 